How do different types of interorganizational ties matter in technological exploration? Peer-reviewed author version

Su, Yu-Shan \& VANHAVERBEKE, Wim (2019) How do different types of interorganizational ties matter in technological exploration?. In: MANAGEMENT DECISION, 57(8), p. 2148-2176.

DOI: 10.1108/MD-06-2018-0713

Handle: http://hdl.handle.net/1942/29880 


\title{
How do Different Types of Interorganizational ties Matter in Technological Exploration?
}

\author{
Wim Vanhaverbeke \\ ESADE Business School, Barcelona, Spain \\ Neoma Business School, Paris, France \\ Email: wim.vanhaverbeke@,neoma-bs.fr \\ Yu-Shan $\mathrm{Su}^{*}$ \\ National Taiwan Normal University, Taipei, Taiwan \\ Email:yssu@ntnu.edu.tw
}

*Corresponding Author: Wim Vanhaverbeke, Tel.: +32 478332440 ; Email: wim.vanhaverbeke@neoma-bs.fr 


\title{
How do Different Types of Interorganizational ties Matter in Technological
}

\author{
Exploration?
}

\begin{abstract}
Boundary-spanning exploration through establishing interorganizational ties is an effective strategy to explore technologies beyond local search in innovating firms. We argue that it is useful to make a distinction in boundary-spanning exploration between what a firm learns from its partners (explorative learning from partners (ELP)) and what it learns from other organisations (explorative learning from non-partners (ELN). Next, we contend that interorganizational ties play a role in both types of exploration. More specifically, we discern three types of ties (inside ties, clique-spanning ties and outside ties) based on their role vis-à-vis existing network cliques. Clique members are highly embedded and breaking out of the cliques through clique-spanning and outside alliances is crucial to improving explorative learning. Thereafter, we claim that clique-spanning ties and outside ties have a different effect on ELN and ELP. The empirical analysis of the ASIC industry indicates that inside ties have negligible effects on both types of explorative learning. Clique-spanning ties have a positive effect on ELP, but not on ELN. The reverse is true for outside ties. The results show that research on explorative learning should devote greater attention to the various roles technology partners play in advancing technological exploration. The literature only emphasises the learning from partners, focusing on accessing their technology, but there is virtually no attention paid to their role as a 'radar' to detect new technologies. In sum, partners play different roles in exploration, and their network position influences the role they are able to play.
\end{abstract}

Keywords: explorative learning from partners, explorative learning from non-partners, boundary-spanning exploration, inside ties, clique-spanning ties, outside ties, conduits, prisms 


\section{INTRODUCTION}

Firms rely increasingly on external partners to explore new technologies (e.g., Rosenkopf and Nerkar, 2001; Lavie and Rosenkopf, 2006; Eriksson et al., 2016; Lavie, Kang and Rosenkopf, 2011; Stettner and Lavie, 2013). Explorative learning implies that firms assimilate and integrate knowledge that resides outside its corporate boundaries. Furthermore, there is convincing empirical evidence that technology alliances are instrumental for technological exploration (Gulati, 1998; Lavie and Rosenkopf, 2006; Lin et al., 2007).

Innovating firms can explore external technologies in different ways. The literature has emphasised the role of explorative learning through alliances and other formal interorganizational relationships. However, firms can also explore new technologies through their exposure to scientific publications (McMillan et al., 2000), patent releases, contact with consultants, technology providers and intermediaries (Howells, 2006), product introductions in the market, conferences, exhibitions, benchmarking with competitors (Wiersema and Bowen, 2008; Hunt and Morgan, 1997), mobility of personnel, etc. These are just a few examples to illustrate how firms explore new technologies by relying on knowledge from organisations with which they have no formal innovation ties.

Given these multiple external sources of explorative learning, we suggest refining the concept of boundary-spanning explorative learning, as it was first introduced by Rosenkopf and Nerkar (2001), in two consecutive steps. First, boundary-spanning explorative learning can be split into two categories with respect to a firm's existing formal relationship network: in boundary-spanning explorative learning, innovating 
companies learn from their partners (Schotter et al., 2017). However, they can also learn from organisations with which they have not established any formal relationships. Second, this distinction allows us to define two roles of alliance partners in firms' explorative learning. Firstly, a firm can learn from its alliance partners' technology (we label this explorative learning from partners or ELP). Learning from external partners is not new and has been discussed extensively in the literature. Secondly, a firm can also explore new technologies based on knowledge from firms with which it has not established any formal relationship in the past (we label this explorative learning from non-partners or $E L N)$. In ELN, technology-sourcing partnerships may foster exploratory learning by bringing a firm into contact with interesting sources of technology. Partners are thus acting as a reputation reference, or by informing a focal firm about new technological opportunities beyond its partners' network (Podolny, 2001; Gulati, 1998; Ghosh and Rosenkopf, 2014; Singh, Kryscynski, Li and Gopal, 2015). To date, innovation management literature has emphasised the role of alliance partners as external sources of knowledge (or ELP) and has neglected explorative learning from non-partners (ELN).

More specifically, we are interested in finding out what type of formal agreements is conducive to both types of explorative learning. Two key questions have to be addressed; (1) How a firm's formal interorganizational relations do contribute to the two types of explorative learning? (2) Do different types of formal relations play a different role in both types of explorative learning? To provide an answer to the second question, we classify technology partnerships into three groups - inside ties, cross-spanning ties, and outside ties. The last two types are related to cross-boundary technological exploration, but the mechanisms are different. We try to explain how the three types of formal 
agreements affect these two types of exploration.

Network theory developed two perspectives to analyse the effects of interorganizational networks on technological exploitation and exploration. The first view focuses on brokerage as the primary driver of technological exploration (Burt, 1992). The second view argues that technological exploration is driven by cohesiveness (Coleman, 1988). To propose how the three types of alliances affect the two types of technological exploration, we use the cohesiveness perspective for inside ties and the brokerage perspective for cross-spanning ties and outside ties. While cohesiveness promotes a more in-depth exploitative search, brokerage pursues a broader explorative search. However, explorative search has not been subcategorised before. The distinction between explorative learning from partners (ELP) and from non-partners (ELN) has not been examined theoretically and empirically in prior studies. In our view, this opens up new ways in which the role of alliance partners in exploration may be considered. We argue that companies not only set up interorganizational ties to learn from their partners, but they also benefit from the 'radar' function these partners play in reaching out to new, hitherto unknown technologies. This framework is empirically tested in the context of the Application Specific Integrated Circuits (ASIC) industry, a sub-sector of the semiconductor industry covering the entire population of ASIC producers in the period 1987-2000.

The contribution to the literature is threefold: First, we categorise two types of technological exploration, further refining the insights in the literature about explorative learning. Second, we consider that the role of partners is no longer restricted to the co-development of new technologies, but they are also instrumental to a focal firm in 
reaching out to novel and useful sources of technologies. Third, different types of relations with partners have a different effect on the two types of exploration. Therefore, a firm has to carefully select the right partners when it intends to boost its explorative learning. In short, the contribution of our study lies not only in estimating the impact of these types of interorganizational relations on technological exploration, but also in the light it sheds on a novel distinction between two types of technological exploration that has not been investigated in previous research.

\section{THEORETICAL BACKGROUND}

\subsection{The Role of Boundary-spanning Technological Exploration}

Local search has been defined as the behaviour of organisations to search for solutions in the neighbourhood of their current expertise or knowledge (Stuart and Podolny, 2000; Phelps, 2010). Empirical evidence suggests that firms focus their technology search on closely related technological domains. By engaging in local search, firms can focus on similar technology and create incremental innovations (Laursen, 2012). And then firms can become even more expert in the technological domains they already master. Local search is beneficial when the competitive environment is stable and the technology dynamic is cumulative. However, core competencies can rapidly turn into core rigidities or fall into competency traps when new technologies emerge or when the competitive environment is changing rapidly (Leonard Barton, 1992; Ahuja and Lampert, 2001; Kim, Song and Nerkar, 2012). Under these circumstances, local search creates inertia, with the result that local search inhibits explorative search (Cyert and March, 1963; Hannan and Freeman, 1984). But, firms can overcome local search by deliberately 
repositioning themselves technologically. They can take action to explore emerging technologies and develop new technological capabilities in-house in order to secure long-term growth (Sirén, Kohtamäki, Kuckertz, 2012).

Technological exploration cannot be achieved without searching activities beyond the boundaries of the firm (Rosenkopf \& Nerkar, 2001; Rosenkopf \& Padula, 2008). Exploratory search involves a conscious effort to look beyond the current knowledge base, in contrast with local search, where companies only use and extend their existing knowledge base (Katila and Ahuja, 2002; March 1991; Laursen, 2012). Firms have to reach out for new technologies, because existing technological capabilities have a limited capacity to generate innovative products, leading inevitably to declining growth opportunities for the company. Firms that search systematically for externally developed knowledge have better access to new information and technology, and in this way they improve their capability to explore new technologies.

Previous research shows that firms must explore valuable knowledge which is developed by other organisations (Chesbrough, 2003; Laursen and Salter, 2006; Menon \& Pfeffer, 2003; Rosenkopf \& Nerkar, 2001). Many innovative firms have changed the way they search for new ideas, adopting open search strategies that involve the use of a wide range of external actors and sources to help them achieve and sustain innovation. The focus on tapping into external knowledge in studies of innovation reflects that the network of relationships between the firm and its external environment plays an increasingly important role in shaping performance.

Rosenkopf \& Nerkar (2001) and Rosenkopf \& McGrath (2011) also argue that exploration beyond organisational boundaries persistently leads to better innovation 
performance. Therefore, search beyond the organisational boundaries becomes a major determinant in explaining the performance differences between firms. In short, innovating firms have to get involved in technological exploration and they are encouraged to explore technology externally, because nowadays useful knowledge is widely distributed (Chesbrough 2003; Bogers, Chesbrough \& Moedas, 2018).

\subsection{Two Types of Technological Exploration}

Firms have to learn from other organisations to move beyond local search and explore new technological opportunities. But who are these organisations from which firms can learn? A broad stream of literature has focused on technology alliances as a major conduit to source external technology or to co-develop technology with other organisations with complementary skills and capabilities (Hagedoorn, 1993; Gulati, 1995; Podolny, 1994; Gulati, Lavie and Singh, 2009). Although the literature has emphasised the role of technology alliances in explorative learning, companies have several options to explore new technologies. Firms can learn, for example, from scientific publications (McMillan et al., 2000), patent releases, contact with consultants, technology providers and intermediaries (Howells, 2006), product introductions in the market, conferences, exhibitions, benchmarking with competitors (Wiersema and Bowen, 2008; Hunt and Morgan, 1997), crowds (Afuah and Tucci, 2012, 2013), mobility of personnel, etc. These are just a few examples to illustrate that the establishment of formal interorganizational ties is only one way - although an important one - to source new technologies. In our view, the literature has underemphasised the role of these alternative ways to source new technologies. Therefore, we make a distinction between two types of explorative learning. 
We have labelled the first type "explorative learning from partners" (ELP). In ELP, a firm explores new technologies through establishing interorganizational relations with different partners. These ties are a formalised way of sourcing and co-developing technological knowledge. Most of these ties are alliances: some are equity-based, others focus on contractual agreements between partners. Recently, new forms of formal innovation relationships have been developed, such as accelerators, incubators, use of knowledge intermediaries / brokers, etc (Weiblen and Chesbrough, 2015). Secondly, a firm can learn from organisations with which it has not established alliance agreements. We have labelled this second type "explorative learning from non-partners" (ELN). ELN refers to organisations on whose technologies a focal firm can build its new technological capabilities without having established any interorganizational ties in the past.

We thus differentiate between two types of technological exploration. ELP or explorative learning through alliance partners has been studied extensively in the literature. In contrast, ELN has not captured the attention of researchers so far. In this study, we show that ELN is important and should be analysed in conjunction with ELP, in order to understand how firms actually rely on other organisations' knowledge to explore new technologies.

The distinction between ELN and ELP also allows us to disentangle two different roles of technology partners in explorative learning. First, we will look at the role of these partners in ELP. Interorganizational relations are usually examined as a conduit of knowledge. The knowledge base of the partners to whom a company has access to is the main reason why technology partnerships are established. An technology agreement between two firms provides a reliable channel through which each partner can learn about 
the competences and the trustworthiness of the other (Rosenkopf \& Padula, 2008). Thus, tehnology agreements are interesting instruments to facilitate explorative learning. Explorative learning entails both exogenous uncertainty (technological and market uncertainties) and endogenous uncertainty (opportunistic behaviour of the alliance partner) (Van de Vrande et al., 2006). And alliance agreements can be shaped in a way that minimises these risks. Over time, alliance experience can generate trust between partners (Gulati, 1995b). Trust reduces transaction cost and uncertainties involved in information sharing and transfer (Dyer and Chu, 2003; Li et al., 2008). Overall, alliance experience or repeated ties between partners is a mixed blessing in technological exploration. On the one hand, formal technology relations between organizations can reduce cost and uncertainties; on the other hand, a focal firm may not learn novel technologies from partners with whom it has already set up several technology projects in the past.

Interorganizational relations have the second role in explorative learning. This role has not been established in the literature and is related to explorative learning from non-partners (ELN). In ELN, technology partners may foster exploratory learning by connecting a focal firm with interesting sources of technology. They thus act as a reputation reference, or inform the focal firm about new technological opportunities. Thus alliance partners play the role of a radar to discover new technological opportunities, as well as a reputation reference to facilitate the contacts between the focal firm and the potentially interesting sources of new technologies (Podolny, 2001; Gulati, 1998). As a result, the function of networks provides a vehicle for gathering information about potential partners through effective referrals (Burt, 1992; Rosenkopf \& Padula, 2008). Due to their contacts with different technology providers, partners can provide the focal 
firm with social cues about the reliability of potentially interesting technology sources in other organizations that are not part of the formal network, thereby reducing the search costs and risks of exposure to opportunistic behaviour (Rosenkopf \& Padula, 2008).

So, partners can also act as referrals or reputation references. Podolny (2001) argues that "the presence or absence of a tie between two market actors is an information cue on which others rely, in order to make inferences about the underlying quality of one or both of the market actors" (p.35). When a focal firm has partners with strong technologies and a solid reputation in the industry, these can act as a referral for the focal firm among other organisations with interesting technologies, or they can facilitate the contact between the latter and the focal firm.

\subsection{Interorganizational relations and technological exploration}

Why and how do interorganizational ties have an impact on innovative firms' technological exploration? Many previous studies have shown the positive impact of these ties on technological innovation and exploration (e.g. Ahuja, 2000; Capaldo, 2007; Powell et al., 1996; Belderbos, Leten and Van Looy 2010; Hoang and Rothaermel, 2009; Garriga, von Krogh, Spaeth, 2013). These scholars argue that innovative firms sustain their innovative performance by tapping into the overall architecture of their formal collaborations. Interorganizational relations are structured as small worlds, characterised by clusters of locally embedded firms connected by a handful of "shortcuts" (Watts and Strogatz, 1998; Watts 1999; Gulati, Sytch and Tatarynomicz, 2013). Clusters are characterised by strong cohesion between partners, and linking with partners within a cluster will be useful in order to reach information in a familiar context. For technological 
exploration, however, companies have to establish formal ties with partners outside the cliques to tap into new and unfamiliar technological knowledge. Because cluster-spanning ties serve as bridges spanning the structural holes across clusters, their use suggests access to less familiar contexts compared to that of prospective partners residing within the same cluster (Burt 2005). Therefore, ties crossing the cluster boundaries are essential in explaining explorative learning. Consequently, boundary-spanning explorative learning should be analysed in the context of the small world characteristics of interorganizational ties, in which ties that cross cluster boundaries play a crucial role (see also Baum et al., 2003).

As a result, we study the impact of alliances on technological exploration by focusing on the role of cliques in these alliances. Cliques are relatively stable groups of firms which are more densely interconnected to one another than other firms in the network (Wasserman and Faust, 1994). Cliques are sparsely connected by a small number of ties that cut across the cliques, linking network members through a relatively small number of intermediaries and acting as conduits for information and control (Baum et al., 2003). Previous studies have shown that clique membership provides clique members with benefits, but creating links across cliques is also advantageous for the performance of clique members (see, for example, Rowley et al., 2004; Rowley et al., 2005; Shipilov, 2005).

To explore explorative search, we examine how clique members can benefit from different types of alliances. We categorise interorganizational ties in relation to their role vis-à-vis the clique to which the clique members belong. We distinguish between three types of ties: "inside ties" with other firms which are members of the same clique, 
"clique-spanning ties" linking the firm to partners in other cliques, and "outside ties" linking the firm with "peripheral" firms. Peripheral firms are companies that do not belong to a clique and they are usually found in the periphery of a network, with few connections to companies in the rest of the network. Thus clique members can reach across the boundary of the clique in two ways: firstly, "clique-spanning ties" make a bridge to partners in another clique. Secondly, "outside ties" link a clique member to firms which are not a member of a clique themselves.

\section{HYPOTHESES}

We use two complementary views of social network theory cohesion and brokerage. Coleman (1988) examined the advantages of cohesion and redundant ties, while Burt (1992) emphasised the advantages of brokerage and bridging ties in the networks. While brokerage provides access to a wider variety of knowledge in stimulating new value creation, cohesiveness helps to integrate this knowledge to deliver value and generate innovation (Capaldo, 2007; Gargiulo and Benassi, 2000; Padula, 2008; Tiwana, 2007). On the one hand, the advantages of inside ties are based on the cohesiveness of the clique. On the other hand, the advantages of clique-spanning ties and outside ties are based on brokerage in the alliances. Cohesive structures promote a deeper search of technological areas with which a firm is already familiar, since with inside ties it connects to firms that have ties with the existing alliance partners of the focal firm. Inside ties are assumed to be instrumental for technological exploitation. In contrast, bridging structures such as cross-spanning ties and outside ties bring the focal firm into contact with partners who do not usually have any ties with the existing alliance partners of the focal company 
themselves. In this way, we expect that clique-spanning ties and outside ties might be instrumental for firms which pursue a broader search strategy to explore new technologies. Having made a distinction between ELP and ELN in the previous section, we argue that these three types of alliances should have the different impacts on both types of technological exploration.

\subsection{Inside ties and explorative learning}

Inside ties are ties between firms in the same clique. Alliance cliques are characterised by strong and repeated ties within cohesive networks (Burt, 1992). Highly cohesive ties with many connections linking one partner in the alliance to another are said to improve the innovativeness of the alliance members (Coleman, 1988; Ahuja, 2000; Lazzarini, 2007; Rowley et al., 2004; Guler and Nerkar, 2012; Padula, 2009). Over time, ties inside existing cohesive networks exert a positive impact on the innovative capability of the firms, since they create trust and reciprocity norms that facilitate knowledge sharing between the clique members. However, inside ties also generate isomorphism between firms within the clique, thereby decreasing network diversity and firms' access to non-redundant knowledge (Burt, 1992). In other words, inside ties may be useful to develop and refine the current knowledge base of a firm, but they are rather a liability for explorative learning, since they limit firms' access to new or non-redundant information. A newly established inside tie delivers redundant information, because the focal firm was already connected to alliance partners of the new partner. The dense network of ties provides many redundant paths to the same nodes and the same sources of information (Burt, 1992; Granovetter, 1973). Therefore, we expect that inside ties will not be instrumental in invigorating explorative learning among clique members. Hence, we 
argue that inside ties have a negligible effect on explorative learning from partners.

Similarly, there are reasons to assume that inside ties have no beneficial effects on explorative learning from non-partners. In ELN, the partner should enable the focal firm to come into contact with new external sources of technology. However, inside ties reinforce the tendency to stick with embedded partners, who have similar information about new technologies and about other technology sources as the other partners in the clique. Thus, inside ties tend to insulate firms and prevent them from exploring beyond their existing networks (Capaldo, 2007; Padula, 2008; Gulati, 1995a; Uzzi, 1997). In sum, inside ties reduce the scope of explorative search. Hence, we hypothesise:

Hypothesis 1a: Inside ties have a negligible effect on both explorative learning from partners.

Hypothesis 1a: Inside ties have a negligible effect on both explorative learning from non-partners.

\subsection{Clique-spanning ties and explorative learning}

Clique-spanning ties connect a firm belonging to a clique to a partner who is a member of another clique. A clique-spanning tie is thus a bridging tie between two cliques (Burt, 1992), spanning a structural hole that separates two cliques. In this way, a firm can access less familiar technologies compared to those developed by partners who reside within the same clique (Burt, 2005; Rosenkopf and Padula, 2008; Cowan and Jonard, 2009). Clique-spanning alliances can create the brokerage advantages. Only a few competitors have the same type of ties, which, in turn, generates a competitive advantage for the focal firm (Burt, 2005; Rosenkopf and Padula, 2008). Therefore, clique-spanning 
ties provide a reliable channel through which each partner can learn about new technologies. As the heterogeneity of alliance partners increases, the range and diversity of ideas, perspectives and information increase too. Clique-spanning ties expose firms to novel alternatives and broader, varied knowledge that enables them to explore more and generate breakthrough innovations (Katila \& Ahuja, 2002; March, 1991; Cowan and Jonard, 2009).

Also, clique-spanning ties have another advantage. In a clique-spanning tie, the partner is acquainted with the technology of its own partners in the clique, which implies that the focal firm not only can learn about the technology of its partner but also about the knowledge generated by its partner's partners in the same clique. Clique-spanning alliances create brokerage advantages (Burt, 2005; Rosenkopf and Padula, 2008). By definition, only a few competitors will have the same type of ties, and this, in turn, generates a competitive advantage for the focal firm. Therefore, clique-spanning ties are instrumental in improving explorative learning from partners.

Do clique-spanning ties also facilitate explorative learning from non-partners? In other words, do partners bring the focal firm into contact with new interesting technology sources? As mentioned earlier, a clique member is highly embedded in its own clique. Highly embedded firms risk generating a cognitive lock-in, which isolates it from the outside world (Capaldo, 2007; Padula, 2008). The strong embeddedness within its clique of partners will prevent it from having a broad overview of the technologies beyond the clique (Uzzi, 1997). The focus of the partner on its partners in the same clique prevents it from staying in continuous touch with other or novel sources of technology. Consequently, we argue that clique-spanning ties will not have a significant impact on 
explorative learning from non-partners. Hence, we hypothesise:

Hypothesis 2a: Clique-spanning ties have a positive effect on explorative learning from partners.

Hypothesis 2b: Clique-spanning ties have no effect on explorative learning from non-partners.

\subsection{Outside ties and explorative learning}

Outside ties connect a focal firm to non-redundant contacts with unique information that inside ties and clique-spanning ties cannot provide. The partners in outside ties have a peripheral position in the network of ties. Their knowledge is, by definition, non-redundant. Moreover, they have a peripheral position because they are new in the industry or they have developed knowledge about alternative or emerging technologies. Therefore, outside ties are beneficial for firms' explorative learning from partners, because they are conduits to new, unique and heterogeneous information (Granovetter, 1973; Hansen, 1999). However, although the information from outside ties may be very valuable, partners in outside ties are not embedded in a rich set of ties themselves. Hence, an outside tie will provide information about the technology of the partner, but since the partner is poorly connected to other organizations it will not incorporate knowledge from these partners (as in the case of cross-spanning ties). Therefore, we argue that outside ties will have only a moderate positive effect on explorative learning from partners (ELP).

Alliances with peripheral firms also give a firm access to a wide spectrum of new information and help to deal with technological dynamics (Lin, Yang, Arya, 2009). In outside ties, the partner is peripheral in the network and can, therefore, bring the focal 
company into contact with new or unfamiliar sources of information and technology. In contrast with clique-spanning ties, the partner is not hindered through its clique-embeddedness from staying in touch with other remote sources of technology. Therefore, we expect that outside ties promote explorative learning from non-partners by bringing the focal firm into contact with a wider range of technological knowledge. Outside ties provide a vehicle for gathering information about technology sources through effective referrals by the partner in knowledge fields with which the focal firm is not familiar. Hence, we hypothesise:

Hypothesis 3a: Outside ties have a moderately positive effect on explorative learning from partners

Hypothesis 3b: Outside ties have a positive effect on explorative learning from non-partners.

\subsection{Technological capital and explorative learning}

To understand a firm's explorative learning, we should also focus on the technological capital of the focal firm. In explorative learning, a firm should have enough absorptive capacity to access, assimilate and integrate external technological knowledge (Cohen \& Levinthal, 1990; Lane and Lubatkin, 1998; Fabricio, 2009). To acquiring the external knowledge successfully, a firm needs to possess prior knowledge that facilitate the absorption of external knowledge. Absorptive capacity is crucial for explorative learning, since the knowledge by definition is relatively new for the firm. A firm's technological capital can help to recognise relevant external knowledge sources and assimilate that knowledge more easily (Cohen \& Levinthal, 1990). We expect that this is 
the case for both types of technological exploration.

Hypothesis 4a: An increase in the technological capital (of a focal firm) will have a positive effect on explorative learning from partners.

Hypothesis 4a: An increase in the technological capital (of a focal firm) will have a positive effect on explorative learning from non-partners

Technological capital plays a dual role in relation to explorative learning. On the one hand, a firm's technological capital enhances its explorative learning, since the firm has a stronger absorptive capacity to source knowledge from outside sources and to use this knowledge to generate new product and process innovations. On the other hand, technological capital also negatively moderates the impact of inter-firm ties on explorative learning from partners. Interorganizational ties may facilitate access to complementary resources that are needed to explore new technologies. Companies can team up with other companies to monitor and stay in touch with the latest technological development as well as to support the transfer and integration of external knowledge. There is, however, a possible substitution effect between technological alliances as a major organisational mode to acquire external and internal knowledge of these technologies. Companies with strong technological capital may not profit as much from their partners as firms with less technological capital. In the case of a firm with strongly technological capital, there is a higher probability that the ties with its partners will not lead to explorative learning, but rather exploitative learning. This is because a technologically savvy firm will have already developed some technological expertise in a particular technological field. In contrast, in the case of companies with smaller 
technological capital, there is a higher probability that they will increase their explorative learning, since interorganizational ties can help them to overcome their internal technological weaknesses.

In other words, larger technological capital can reflect the diversity of technologies in which the company is involved (especially for large multidivisional companies), while smaller technological capital can reflect the specialisation of a firm in a particular technology. Generally speaking, the specialised firm has a greater opportunity than the diversified company to explore new technologies through its alliances. As a result, the larger the technological capitals, the lower the impacts of alliances on explorative learning from partners.

On the contrary, technological capital does not play a similar role in explorative learning from non-partners. We do not expect that technological capital influences explorative learning from non-partners. Here, partners play the role of referrals and 'radars' to find new technology sources. A focal firm can benefit from this radar and referral function of its partners, and this effect will not be influenced by the strength of its technological capitals. Firms with either stronger or weaker technological capitals can benefit from being made aware of technology sources that they were not familiar with before.

We have no a priori reason to assume that these hypothesised effects of technological capabilities on ELP and ELN differ among the three types of alliances. Thus, we hypothesise:

Hypothesis 5a: Technological capital negatively moderates the effect of the three types of ties on explorative learning from partners. 
Hypothesis 5a: Technological capital does not affect the effect of the three types of ties on explorative learning from non-partners.

\section{EMPIRICAL SETTING}

Our hypotheses are tested on the population of ASIC producers that were active in the period 1987-2000. ASICs - application specific integrated circuits - are a special type of IC (integrated circuit) that accounted for about 12\% of worldwide IC sales in 1999. The ASIC market is a typical high-tech industry in which technology is the driving force, shaping competition among firms, and R\&D-to-sales ratios are exceptionally high. In contrast with the general purpose ICs such as DRAMs and microprocessors, ASICs are built to perform only one particular function, e.g., converting digital signals of a $\mathrm{CD}$ or MP3file into music. ASIC technology has been around since the early 1970s, but the industry began to show strong development in the early 1980s, when various electronic devices such as the desktop computer and the microprocessor became a success. IC customers started to realise that a good custom designed IC could give them a sustainable competitive advantage over their competitors, and they were willing to pay for IC design together with the fixed costs of IC production. The industry started out with ASIC products offered by large integrated IC companies or produced in-house by large manufacturers of electronic devices (e.g., IBM and Texas Instruments). The increasing complexity and specialisation of ASIC products initiated a process of start-ups and spin-offs between 1980 and 1990, with companies focusing exclusively on the ASIC industry. 
The ASIC market is divided into three segments: semi-custom ASICs, such as gate arrays and linear arrays, custom ASICs, such as full custom and standard cells, and programmable logic devices (PLDs), such as field programmable gate arrays (FPGA) and electronically programmable analog circuits (EPAC). Formal definitions are given in Table 1 (Source: ICE ASIC-Outlook industry reports, McClean, 1987-2000) and diagrammed in Figure 2. Firms may be involved in just one of these segments, or in more segments at the same time. Segments are important in the sense that firms in each segment face different competitors, technologies and competitive or technological dynamics. Customers typically make a decision between the three ASIC segments based on the total cost per chip, which in turn is dependent on the production volume and the design complexity. PLDs are the cheapest solution for simple and low volume production, while full custom designs are the most efficient solution for production volumes that exceed several hundred thousand ASICs.

Insert Table 1 about here

Insert Figure 1 about here

The development and production of ASICs requires interplay between various economic agents. The most important participants are the ASIC design houses, IC manufacturing facilities, electronic system manufacturers and CAD tool vendors. To this list we might add a number of auxiliary and/or intermediate players, such as companies 
offering services in the microelectronics field, firms that translate customers' needs into the specifications for the design of ASICs, and university labs. Some large system manufacturers have their own ASIC design house and foundry, or they acquire one, but even in this case they still cooperate with specialist design houses on account of recurrent peaks in design work. Large electronic system manufacturers seek to gain a foothold in the ASIC market by vertical integration: they aim to achieve a competitive advantage for their electronic systems through proprietary ASIC designs. These large, integrated electronic system manufacturers usually have their own fablines and their ASICs are processed together with standard ICs. They also make corporate-wide deals and second-source agreements with foundries. Smaller electronic companies set up agreements with different foundries and vendors to design and process their ASICs. As ASIC designs become increasingly complex, companies establish numerous joint development and cross-licensing agreements. Given these characteristics of the industry, most strategic alliances in the ASIC industry are likely to be strategic tools for external technology sourcing or joint development. In a high-tech environment like the ASIC industry, firms establish strategic alliances with each other in order to keep up with the newest technologies (Duysters and Hagedoorn, 1996), making this an interesting industry for testing our research questions.

\section{DATA AND VARIABLES}

\subsection{Data}

We constructed a panel dataset covering the population of ASIC producers over the period 1987-2000. Based on the vendor list included in the ICE ASIC-Outlook industry 
reports (McClean, 1987-2000), we established a detailed list of all ASIC producers. In order to measure the technological knowledge base of the ASIC producers, we draw on patent data from the US Patent and Trademark Office. In industries like the ASIC industry in which companies operate on a global scale, U.S. patents are a good proxy for companies' worldwide technological performance and technological assets. The data on strategic technology alliances was obtained from the ICE industry reports; the ASIC-Outlook reports (McClean, 1977-2000) and the MERIT-CATI database on strategic technology alliances (Hagedoorn, 1993). Financial data about ASIC producers has been gathered from different sources, including the annual ICE reports (McClean, 1977-2000) and COMPUSTAT.

\subsection{Alliance networks and operationalisation of cliques}

In order to differentiate between the three types of ties, first we have to identify cliques in the network. For each year in the period 1987-2000, we constructed the network in the ASIC industry based on the alliances that were established during the 5 years prior to the year under observation. Based on these networks, we constructed the "cliques". In the construction of the cliques, we needed to formulate a measuring technique for grouping geodesically close firms that also guaranteed a density within the cliques that was higher than a lower bound threshold. Therefore, and in line with prior research on cliques (Rowley et al., 2005), we used the N-Clan procedure implemented in UCINET to detect relevant cliques (Borgatti, Everett \& Freeman, 2002). We defined the maximum path length between all partners in a clique as 2 . The $\mathrm{N}$-Clan procedure allows firms to be a member of more than one clique. In this particular industry, $38 \%$ of the 
firms were members of more than one clique. In accordance with Rowley et al. (2005), firms assigned to multiple cliques were considered to be members of each clique for the purpose of computing the clique-level independent variables. We corrected the firm-level observations for overrepresentation by weighting these observations by the number of cliques these firms participated in. We identified 75 active ASIC producer firms that were located within a clique during the period 1987-2000. This resulted in an unbalanced panel of 643 observations. In total, we found an average of 33 cliques per year during our observation period (1987-2000) ${ }^{1}$.

\subsection{Variables}

\section{Dependent Variables}

We make a distinction between two types of dependent variables: explorative learning from partners (ELP) and explorative learning from non-partners (ELN). We refer to Figure 2 to explain the distinction between both variables. This figure shows how different types of learning can be distinguished by tracking the backward citations of new patents of an innovating firm in a particular year (following Rosenkopf and Nerkar, 2001). When companies build on prior technological knowledge, new patents must cite existing patents on which they build. As a result, patent citations are a unique and reliable instrument to define different types of exploration. ${ }^{2}$.

\footnotetext{
The standard deviation is 5.16. The number of cliques varied over the years from 26 to 42 .

2 We use patents and patent citations as a proxy for knowledge and knowledge flows, in line with the work of others (e.g., Ahuja \& Katila, 2001; Almeida, 1996; Hoetker \& Agarwal, 2007; Jaffe et al., 1993; Peri, 2005). Knowledge may flow between individuals and firms through a number of mechanisms including conferences, publications, professional social networks and reverse engineering, in addition to patent reviews. Despite the various mechanisms for knowledge flow, knowledge and knowledge flows often leave their footprint in the form of patents (Jaffe, 1986). As a result, patents are an effective proxy for knowledge regardless of the mechanism. The fact that examiners add citations to patent applications is not really a concern here. Independent examiners are involved in assessing the
} 
Insert here Figure 2

In some cases, firms invent new technologies that do not build on any prior art. These "pioneering technologies" have no technological antecedents and they represent the technologies that do not build on any existing technologies (Ahuja and Lampert, 2001). We can further distinguish two different cases when a new patent cites prior patents. On the one hand, a new patent can cite some of the firm's own patents. Self-citations imply that the new patent is built on the firm's prior expertise and experience. This type of patent represents a firm's exploitative learning (Benner and Tushman, 2002; Rosenkopf and Nerkar, 2001; Schildt et al., 2005). Through exploitation, firms extend and refine their existing technical capabilities that are most likely to be the competencies that are crucial for the competitiveness of their current businesses. In other cases, firms can also successfully file new patents that do not cite any of their own prior patents. When a firm's new patents have no backward self-citations, the firm explores new technological areas and broadens its own technological capabilities by building on the knowledge of other organisations. Patents with no self-citations but which cite patents from other firms are considered to be more explorative than those that also cite own prior technology. These patents are important for the purpose of avoiding problems related to local search (March and Simon, 1958; Nelson and Winter, 1982; Helfat, 1994; Eriksson et

prior knowledge on which an innovation builds. The criticism may be made that these citations included by examiners do not reveal how a firm is building its technology on that of other companies. However, we feel comfortable that this is not a major issue for two reasons: firstly, as we mentioned earlier, learning is not necessarily based on explicit patent reviews. Secondly, should these citations be considered as random noise, then we can argue that if the empirical results in this paper reveal interesting relations, then they would be a priori hold in case we could eliminated the patent citations that the patent examiners added. Moreover, these extra citations lead to a better measure of the knowledge that an innovation actually builds upon. 
al. 2016).

So far, we have been using existing definitions of technological exploitation and exploration (Rosenkopf and Nerkar, 2001). We further segment exploratory patents into two subcategories. On the one hand, innovating firms may avoid local search by learning from their partners. A patent is categorised as explorative learning from partners when there are no self-citations and when some backward citations refer to organisations with which the innovating firm has established one or more alliances during the last 5 years (Benner and Tushman, 2002; Schildt, et al., 2005). In contrast, a patent is categorised as explorative learning from non-partners when there are no self-citations and when there are only backward citations referring to organisations with which the innovating firm established no alliances during the last 5 years. This moving window approach is considered to be an appropriate timeframe during which the existing portfolio of strategic alliances is likely to have an influence on the current technological performance of a firm (Kogut, 1988, 1989; Gulati, 1995a).

Both dependent variables are count variables, indicating the number of new patent applications that fulfil the requirements of explorative learning from partners (ELP) or explorative learning from non-partners (ELN). ELP is calculated as the sum of patents successfully applied for by the focal firm in each year ${ }^{3}$ which have at least one citation to its alliance partners' prior patents, but no citations to its own prior patents. ELN is calculated as the number of patents successfully applied for per year by the focal firm which neither cites its own prior patents nor its alliance partners' patents.

\section{Independent Variables}

3 "Patents successfully applied for" implies that these patents have been granted. However, we do not allocate a patent to the year it was granted, but prefer to allocate it to the year it was applied for, because at that time the invention had already been made. 
The independent variables are based on the alliance networks in the ASIC industry and the cliques defined above. The cliques are derived from the alliances established during the five years prior to the year of observation. Companies can change their position in a clique by establishing new ties, and dissolving, strengthening or weakening existing ones (Koka, Madhavan and Prescott, 2006). The new ties that are established by clique members can be classified as "inside clique ties", "outside clique ties" and "clique-spanning ties". If a newly established alliance in year $\mathrm{t}$ bridges two distinct cliques in the existing alliance network, then it can be considered a clique-spanning tie. Inside ties link two firms within the same clique and outside ties link a clique member to a firm which is not a member of a clique (we also label these partners as peripheral network members, since they are not part of the main pack in the alliance network). After categorising these ties, the number of clique-spanning ties can be measured by counting the number of clique-spanning ties that a firm initiated 5 years prior to the observation year.

\section{Control Variables}

We include three organisational variables and four dummy variables to control for unobserved effects. In order to control for unobserved heterogeneity at the firm level, we included the variable technological capital, representing the total size of a firm's technological knowledge base. This variable was created by adding up all ASIC-related patents that a firm had successfully applied for during the five years prior to the year of observation. A moving window of 5 years is considered to be an appropriate time frame for assessing technological impact in high-tech industries (Podolny and Stuart, 1995; Henderson and Cockburn, 1996). The second firm-level variable relates to the size of the 
firm. Large firms have a broader and more diversified established network of alliances (Hagedoorn and Duysters, 2002) and position themselves as dominant firms, not only within the clique, but also in the overall alliance network. Due to their size advantage, large firms are more likely to profit from economies of scale and scope, and so they have a higher potential to increase their technological performance over time. We calculated this variable as the natural logarithm of a firm's annual sales. The third firm-level control variable is $R \& D$ intensity. Firms that invest more in $R \& D$ have more options to explore and experiment with new kinds of technologies. We calculated this variable based on the $R \& D$ to sales ratio of each firm.

Furthermore, we include four types of dummy variables to control for different types of contingencies. A first dummy variable was included to control for a potential bias,since some large companies only produce ASICs to cover their internal needs (captive sales). These captive producers represent a small minority of ASIC-producing companies, but they are nonetheless important in terms of technological capabilities; consequently, they play an important role in the technological development of the ASIC industry (e.g., IBM and Texas Instruments). A second industry dummy variable is included to indicate the industry to which an ASIC producer belongs. Firms can be involved in the production of just one segment or in more segments of the ASIC industry at the same time. Segments are important in the sense that firms in each segment face different competitors, technological challenges, and competitive or technological dynamics. The third dummy variable indicates the economic region in which the company is headquartered (Asia, North America or Europe), the default being North America (Ohmae, 1985). Finally, year dummy variables are included to capture changes over time in the propensity of firms to 
patent their inventions.

Insert Table 2 about here

\section{RESULTS}

In Table 3 and Table 4, we present the descriptive statistics and the correlation matrix for the different variables. Our dependent variables, explorative learning from partners and explorative learning from non-partners, are count variables. Because our data shows evidence of over dispersion, a negative binomial regression model is the most appropriate method (Cameron and Trivedi, 1998). To determine the choice between a random-effect and fixed-effect model, we conducted a Hausman test (1978). The Hausman test indicated that random effects estimators are consistent and efficient for this analysis. Table 4 presents the correlations between the different variables. Except for correlations between main variables and their interaction terms (such as the combinations of the alliance types and technical capital), all correlations among the independent variables are low. However, cross-spanning ties and outside ties are positively related, and the R\&D intensity is negatively correlated to the firm size measure (because many ASIC start-ups have an unusually high R\&D intensity. The results of the regression diagnostics (e.g., VIF statistics) suggested, however, that multicollinearity was not a problem.

Table 5 shows the results of the random effects negative binomial regression analyses for 643 observations (of 80 clique members) in the sample. The left side of Table 5 represents the regressions for explorative learning from partners, the right side 
the regressions for explorative learning from non-partners.

Insert Tables 3-5 here

Model 1 (ELP) and 7 (ELN) are the base model, only including control variables. Model 2 includes the three types of ties ${ }^{4}$. Inside ties do not have a significant impact on either type of explorative learning, providing empirical support for hypothesis 1a: firms partnering with other companies in the same clique will not benefit from these ties when they intend to explore new technologies. In other words, clique members are not the right partners to explore new technologies. As Model 8 shows, nor are clique members of interest as referrals to learn about other relevant external technology sources, since the information these partners provide will be redundant information in most cases; the focal firm already has a lot of information about these sources through the existing partnerships in the clique. This finding supports hypothesis $1 b$.

We expect a positive effect of clique-spanning ties on learning from partners. Model 2 in Table 5 shows that clique-spanning ties have a significant positive impact on exploration from partners, which supports hypothesis 2a. Similarly, we expect outside ties to have an effect on ELP as well. However, this is not the case: outside ties have a positive effect, but the coefficient is not significant. In other words, hypothesis $3 \mathrm{a}$ is not supported by the data.

The opposite effect can be seen for explorative learning from non-partners: here, outside ties have a positive effect on this type of explorative learning, while

4 We also ran the regressions introducing just one type of alliance into the regression. The results are very similar to those reported in Models 2 and 7. 
cross-spanning ties are no significant impact. Thus, we have strong empirical support for hypothesis $2 \mathrm{~b}$ and $3 \mathrm{~b}$ : while outside ties have no effect on ELP, they have a significant positive effect on ELN (see Model 8).

Models 2 and 7 in Table 5 show that there is no immediate effect of technological capital on ELP. In contrast, it has a strong positive impact on ELN. Hence, we have support for hypothesis $4 \mathrm{~b}$, but not for $4 \mathrm{a}$. Model 3-5 in Table 5 show that indicate that technological capital has no immediate effect on explorative learning from partners. In contrast, technological capital has a positive impact on explorative learning from non-partners - see Models 9-11 in Table 5. We comment on this finding in the discussion section.

In hypotheses $5 \mathrm{a}$ and $5 \mathrm{~b}$, we suggested that there is a moderating effect of technological capital on the effect of the different types of ties on explorative learning from partners. Model 3-5 in Table 5 show that technological capital negatively moderates the effect of the three types of alliances on ELP.

The combined effect of the ties and technological capital is represented in Figure 3. Firms with low technological capital profit from the three types of ties, although cross spanning ties have a much bigger effect than the other two. Thus, firms with poorly developed technological capital can benefit not only from clique-spanning alliances, but also to a lesser extent from inside ties and outside ties. When their technological capital increases, then the effect becomes negative for outside ties and inside ties. This result shows that alliances should not be considered independently from technological capital in estimating their impact on ELP. In contrast, technological capital does not moderate the effect of the three types of ties on ELN. This sharp contrast between ELP and ELN - 
corroborating hypotheses $5 \mathrm{a}$ and $5 \mathrm{~b}$ - will be discussed further in the following section.

\section{DISCUSSION}

This study investigates the effect of three types of interorganizational ties on two types of explorative learning. Firms can learn from their partners, as has been emphasised in prior studies. Firms with more partners will have more opportunities for explorative technologies, building on their knowledge. However, interorganizational ties are formal agreements to learn from external technology sources. In this study, we clarify that partners have two roles in technological exploration: a firm can learn from its partners because they have strong technological capabilities (ELP), or partners may function as a radar, bringing he focal firm into contact with new external sources of new or unexplored technologies (ELN). Furthermore, we analysed the effect of different types of alliances and of internal technological capital on ELP and ELN.

\subsection{Contributions to the theory}

Four contributions emerge from the empirical analysis in this study.

Firstly, we contribute to the literature about technological exploitation and exploration. Only a few studies have shown the reasons why firms try to search beyond their boundaries (Rosenkopf \& Nerkar, 2001; Rosenkopf \& Padula, 2008). We propose that firms can explore new technologies beyond local search, but they can also do this in two different ways. This is one of the first studies to refine the concept of exploration by making a distinction between explorative learning, which focuses on the knowledge bases of the alliance partners, and learning through which a firm uses its technology partners $t$ 
learn from organisations with which it has no formal technology agreements. The last type of exploration has not been studied empirically in the literature.

Secondly, interorganizational ties are important means for exploring new knowledge and technologies, since they allow companies to bridge technological domains effectively (Rosenkopf \& Almeida, 2003). Our study started from the role of cliques: in order to source new technologies, a clique member has to go beyond the boundaries of its clique. We therefore distinguished three types of ties - inside ties, cross-spanning ties, and outside ties- and we examined whether or not they are useful for boosting the two types of explorative learning in the ASIC industry. Our results show that inside ties have a negligible effect on both types of learning. A firm which is strongly embedded in a clique of partners will not experience any help from them in exploring new technological areas. Inside ties do not boost explorative learning from partners (ELP), because the knowledge of an inside tie is redundant, as the new partner was already indirectly connected to the focal firm though other partners in the clique. Inside ties are not productive for learning from non-partners either (ELN), because the new partner will connect the focal firm with technology sources with which it is already familiar from other partnerships in the clique. Cross-spanning ties are expected to have a positive effect on explorative learning from partners. This is fully supported by the results: when a firm can bridge two cliques by setting up a new alliance, it has a great source of technology to tap into. As expected, clique-spanning ties are not useful in advancing explorative learning from non-partners: in clique-spanning ties, partners are heavily embedded in their own clique, preventing them to provide the focal firm with technology sources beyond their own alliance partners. Outside ties, in contrast, have no effect on explorative learning from partners 
(ELP), but they have a positive effect on explorative learning from non-partners (ELN): this implies that the focal firm is not directly exploring new technologies based on its partner's knowledge base. Rather, it sets up an alliance with a partner to learn from new technology fields through the partnership: the partner is instrumental in informing the company about novel technologies and in facilitating access to them. In sum, this study shows that the choice of the right type of ties with partners in the network plays a crucial role in obtaining success with the two types of explorative learning.

Thirdly, our study has research implications on the role of cohesiveness and brokerage in alliance networks (Burt, 1992; Coleman, 1998). A number of studies demonstrate that cohesiveness and brokerage play a complementary role in alliance networks in supporting firms' innovation performance (Capaldo, 2007; Padula, 2008; Schilling \& Phelps, 2007; Tiwana, 2007; Ahuja, Soda and Zaheer, 2012). By distinguishing three types of alliance ties, our study contributes to this line of literature by providing empirical evidence of how the cohesiveness and brokerage of the alliance networks are important in determining the success of the two types of technological exploration. Our results demonstrate that network closure has no effects on either type of technological exploration, while network brokerage shows different effects of cross-spanning ties and outside ties on the two types of technological exploration. Our results support two points: firstly, network closure (or inside ties) may play a positive role in exploitation, but it has no impact on technological exploration (Capaldo, 2007; Gargiulo, Ertug, \& Galunic, 2009); secondly, network brokerage has been identified as an influential determinant for enhancing innovative performance (Ahuja, 2000; Sytch, Tatarynowicz, \& Gulati, 2012; Zaheer \& Bell, 2005). Our results specify that crossing the 
clique boundary with interorganizational ties leads to different results depending on the network position of the partnering firm. Linking up with firms in the periphery has a different effect compared to cross-spanning ties, where partners are members of a clique themselves.

Fourthly, in addition to the main effects of different types of interorganizational ties, our study also shows how technological capital moderates the relationship between the three types of ties and the two types of technological exploration. The best way to study the effect of technological capital on ELP is to show the combined effect of a particular type of tie and technological capital: the results are summarised in the three graphs in Figure 3. The horizontal axis in these graphs represents the technological capital of ASIC producers (up to the mean $+2 *$ st dev). The different lines represent different values for the alliances (zero, mean, mean + st dev, and mean $+2 * s t$ dev). The first graph shows that firms with few clique-spanning ties boost ELP when they have more technological capital. A high number of clique-spanning ties improves ELP drastically, but higher levels of technological capital reduce the effect on ELP. The effect of outside ties and inside ties on ELP is much smaller than in the case of clique-spanning ties. Moreover, relying on these two types of alliances may have a negative effect on ELP at higher levels of technological capital. This is certainly the case for inside ties, where negative values for ELP are recorded at moderate values of technological capital. In sum, relying on alliance partners is positive for companies with poorly developed technological capabilities (but the effect is much smaller for outside and inside ties). Companies with strong technical capabilities should avoid relying on inside and outside ties, while clique-spanning ties still have a positive effect. The effect of technological capital is straightforward in the case of 
explorative learning from non-partners: companies with strong technological capabilities have a greater absorptive capacity to learn from new technology sources beyond their alliance partner network. There is - in contrast with ELP - no interaction between technological capital and the firms' alliances.

\subsection{Managerial implications}

The current study has also some interesting implications for the management of interorganizational ties to maximize explorative learning. First, the concept of using technology partners as a prism (Podolny, 2001) is important and has not received the attention it deserves: technology partners are important for a focal firm because of the technology they own (ELP), but they are also valuable to detect and understand new technologies beyond their own technology (ELN). Technology partners facilitate the

process for a company to learn about new technological developments. Second, given this dual role of partners in explorative learning, it is important to understand the position of the partners in the network. The three types of ties we discussed have different implications for both types of learning. Clique spanning ties are useful for ELP, while outside ties - linking a firm to partners that are peripheral in the network - are instrumental for ELN. Third, managers have to keep in mind that the technological capital in their company hasn't any effect on the impact of the three types of ties on ELN. This is different for ELP: firms with strong technological capabilities experience less benefits from collaborating with technology partners and in the case of inside and outside ties, this may even have a negative effect on explorative learning. 


\subsection{Limitations and Future Directions}

Our research is explorative and limited in several ways. Firstly, the operationalisation of the two types of explorative learning could be criticised. We have been using these concepts in an exclusive way. A patent that cites prior patents of partners is categorised as learning from partners, irrespective of the number of citations to non-partners. The analysis can be improved by developing more sophisticated, continuous variables that range between $100 \%$ partner citations and $100 \%$ non-partner citations. Secondly, the current study can be easily extended to explore both organisational and technological boundary-spanning activities (Rosenkopf and Nerkar, 2001). We have only focused on exploration as an organisational boundary-spanning activity. Including technological boundary spanning would add complexity and would certainly enrich the analysis. Thirdly, we used three types of interorganizational ties: the technology network literature has developed other categorisations of alliances that may be relevant when studying explorative learning. Finally, extending the types of relationships between partners (e.g., licensing, arm's length R\&D-contracting, patent search, informal/personal contacts, crowdsourcing, knowledge brokers, etc.) may also help to obtain a more accurate picture of how external sources of knowledge enhance explorative learning by firms.

Our investigation of the impact of different types of alliances on explorative learning provides new insights on inter-organisational learning. Technological exploration has received considerable attention in the literature, but many questions about how alliances can play a role in boosting explorative learning remain unanswered. We encourage other scholars to further engage in this interesting field of research. 


\section{References}

Afuah, A. and Tucci, C. (2012). Crowdsourcing as a solution to distant search, The Academy of Management Review, 37(3), 355-375.

Afuah, A. and Tucci, C. (2013). Value capture and crowdsourcing, 38(3), The Academy of Management Review, 38(3), 457-46

Ahuja, G. 2000. The duality of collaboration: Inducements and opportunities in the formation of interfirm linkages. Strategic Management Journal, 21: 317-343.

Ahuja, G. \& Lampert, C. M. 2001. Entrepreneurship in the large corporation: A longitudinal study of

how established firms create breakthrough inventions. Strategic Management Journal, 22:

521-543.

Ahuja, G. \& Katilla, R. 2001. Technological acquisitions and the innovation performance of acquiring firms: A longitudinal study. Strategic Management Journal, 22: 197-220.

Ahuja, G., Soda and Zaheer, (2012). The Genesis and Dynamics of Organizational Networks, Organization Science, 23(2), 434-448.

Almeida, P. 1996. Knowledge sourcing by foreign multinationals: Patent citation analysis in the U.S. semiconductor industry. Strategic Management Journal, 17: 155-165.

Baum, J. A. C., Shipilov, A. V. \& Rowley, T. J. 2003. Where do small worlds come from? Industrial and Corporate Change, 12(4): 697-725.

Belderbos, R., Leten, B. and Van Looy, B. (2010). Technological Activities and Their Impact on the

Financial Performance of the Firm: Exploitation and Exploration within and between Firms,

Journal of Product Innovation Management, 27(6), 869-882.

Benner, M. J. \& Tushman, M. L. (2002). Process management and technological innovation: A

longitudinal study of the photography and paint industries. Administrative Science Quarterly, 47:

676-706.

Bogers, M., Chesbrough, H. and Moedas, C. (2018). Open innovation: Research, Practices and Polcies, California Management Review, 60(2), 5-16.

Borgatti, S. P., Everett, M. G.\& Freeman, L. C. 2002. Ucinet 6 for Windows. Harvard: Analytic Technologies.

Burt, R. 2005. Brokerage and closure: An introduction to social capital. Oxford: Oxford University Press.

Burt, R. S. 1992. Structural holes: The social structure of competition. Cambridge, MA: Harvard University Press.

Cameron, A. C.\& Triverdi P. K. 1998. Regression analysis of count data. Econometric Society Monograph No.30, Cambridge University Press.

Capaldo, A. 2007. Network structure and innovation: The leveraging of a dual network as a distinctive relational capability. Strategic Management Journal,28(6): 585-608.

Chesbrough, H. 2003. Open innovation: The new imperative for creating and profiting from technology. Boston, MA: Harvard Business School Press.

Cohen, W. \& Levinthal, D. 1990. Absorptive capacity: A new perspective on learning and innovation. Administrative Science Quarterly, 35: 128-152.

Coleman, J. S. 1988. Social capital in the creation of human capital. American Journal of Sociology, 94(s1): S95-120.

Cowan, R. and Jonard, N. (2009). Knowledge portfolios and the organization of innovation networks, Academy of Management Review, 34(2), 320-342.

Cyert, R. M. \& March, J. G. 1963. A Behavioural Theory of the Firm.Englewood Cliffs, NJ: Prentice-Hall.

Dyer, J. H. \& Chu, W. 2003. The role of trustworthiness in reducing transaction costs and improving performance: Empirical evidence from the United States, Japan, and Korea. Organization Science, 14(1): 57-68.

Duysters, G.M. \& Hagedoorn, J. 1996. Internationalization of corporate technology through 
strategic partnering: an empirical investigation. Research Policy, 25(1), 1-12.

Erikson, P.E., Patel, P.C., Rönnberg Sjödin, D., Frishammar, J., Parida, V. (2016). Managing Interorganizational Innovation Projects: Mitigating the Negative Effects of Equivocality Through Knowledge Search Strategies, Long range Planning, 49(6), 691-705.

Fabricio, K.R. (2009). Absorptive capacity and the search for innovation, Research Policy, 38(2), 255-267.

Gargiulo, M. \& Benassi, M. 2000.Trapped in your own net? Network cohesion, structural holes, and the adaptation of social capital. Organization Science, 11(2): 183-196.

Gargiulo, M., Ertug, G. \& Galunic, C. 2009. The two faces of control: Network closure and individual performance among knowledge workers. Administrative Science Quarterly, 54(2): 299-333.

Garriga, H. and Von Krogh, G. and Spaeth, S. (2013). How constraints and knowledge impact open innovation, Strategic Management Journal, 34(9), 1134-1144.

Ghosh, A. and Rosenkopf, L.(2014). Shrouded in Structure: Challenges and Opportunities for a Friction-Based View of Network Research, Organization science, 26(2), 622-631.

Granovetter, M. S. 1973. The strength of weak ties. American Journal of Sociology, 78(6): 1360-1380.

Gulati, R. 1995a. Social structure and alliance formation patterns: a longitudinal analysis. Administrative Science Quarterly, 40: 619-652.

Gulati, R. 1995b. Does familiarity breed trust? The implications of repeated ties for contractual choices in alliances. Academy of Management Journal, 38: 85-112.

Gulati, R. 1998. Alliances and networks. Strategic Management Journal. 19(4): 293-317.

Gulati, R. 1999. Network location and learning: the influence of network resources and firm capabilities on alliance formation. Strategic Management Journal,20(5): 397-420.

Gulati, R., Lavie, D. \& Singh, H. 2009. The nature of partnering experience and the gains from alliances. Strategic Management Journal,30(11): 1213-1233.

Gulati, R., Sytch, M. and Tatarynomicz, A. (2013). The Rise and Fall of Small Worlds: Exploring the Dynamics of Social Structure, Organization Science, 23(2), 449-471.

Guler, I. and Nerkar, A. (2013). The impact of global and local cohesion on innovation in the pharmaceutical industry, Strategic Management Journal, 33(5), 535-549.

Hagedoorn, J. 1993. Understanding the rationale of strategic technology partnering: Interorganizational modes of cooperation and sectoral differences. Strategic Management Journal, 14: 371-385.

Hagedoorn, J. \& Duysters G.M. 2002. Learning in dynamic inter-firm networks - The efficacy of quasi-redundant contacts. Organization Studies, 23: 525-548.

Hannan, M. T., \& Freeman, J. H. 1984. Structural inertia and organizational change. American Sociological Review, 49(2): 149-164.

Hansen, M. T. 1999. The Search-transfer problem: The role of weak ties in sharing knowledge across organization subunits. Administrative Science Quarterly, 44(1): 82-111.

Hausman, J. 1978. Specification tests in econometrics. Econometrica, 46: 1251-1271.

Helfat, C.E. 1994. Evolutionary trajectories in petroleum firm R\&D. Management Science, 40(12): 1720-1747.

Henderson, R., Cockburn, I. 1996. Scale, scope and spillovers: the determinants of research productivity in drug discovery. Rand Journal of Economics, 27: 32-59.

Hoang, H. and Rothaermel, F.T. (2009).

Hoetker, G. \& Agarwal, R. 2007. Death hurts, but it isn't fatal: The postexit diffusion of knowledge created by innovative companies. Academy of Management Journal, 50, 446-467.

Howells, J. (2006). Intermediation and the role of intermediaries in innovation. Research Policy, 
35(5): 715-728.

Hunt, S. D. \& R. M. Morgan. 1997. Resource advantage theory: a general theory of competition?

Journal of Marketing, 61(3): 74-82.

Jaffe, Adam B., 1986. Technological Opportunity and Spillovers of R\&D: Evidence from Firms' Patents, Profits, and Market Value, American Economic Review, 76(5), pages 984-1001.

Jaffe, A.B., Trajtenberg, M. \& Henderson, R. M. 1993. Geographic localization of knowledge spillovers as evidenced by patent citations. Quarterly Journal of Economics 108(3): 577-598.

Katila, R. \& Ahuja, G. 2002.Something old, something new: A longitudinal study of search behavior and new product introduction. Academy of Management Journal, 45(6): $1183-1194$.

Kim, C., Song, J. and Nerkar, A. (2012). Learning and innovation: exploitation and exploration trade-offs. Journal of Business Research, 65(8), 1189-1194.

Koka, B.R., Madhavan, R., Prescott, J.E. 2006. The evolution of interfirm networks: environmental effects on patterns of network change. Academy of Management Review, 31: 721-737.

Kogut, B. 1988. A study of the life cycle of joint ventures. In: Contractor, F., Lorange, P. (Eds.), Cooperative Strategies in International Business. Lexington Books, Lexington, MA, pp. 169186.

Kogut, B. 1989. The stability of joint ventures: reciprocity and competitive rivalry. Journal of Industrial Economics, 38, 183-198.

Lane, P.J. \& Lubatkin, M. 1998. Relative absorptive capacity and interorganizational learning. Strategic Management Journal, 19: 461-477.

Laursen, K. (2012). Keep searching and you'll find: what do we know about variety creation through firms' search activities for innovation?, Industrial and Corporate Change, 21(1), 1181-1220.

Laursen, K. \& Salter, A. J. 2006. Open for innovation: The role of openness in explaining innovation performance among UK manufacturing firms.Strategic Management Journal,27(2): 131-150.

Lavie, D. \& Rosenkopf, L. 2006. Balancing exploration and exploitation in alliance formation. Academy of Management Journal,49(4): 797-818.

Lavie, D., Kang, J. and Rosenkopf, L. (2011). Balance Within and Across Domains: The Performance Implications of Exploration and Exploitation in Alliances, Organization Science, 22(6), 1517-1538.

Lazzarini, S. G. 2007. The impact of membership in competing alliance constellations: Evidence on the operational performance of global airlines. Strategic Management Journal, 28: 345-367.

Leonard-Barton, D. 1992. Core capabilities and core rigidities: A paradox in managing new product development. Strategic Management Journal, 13(Special Issue: Strategy Process: Managing Corporate Self-Renewal):111-125.

Li, D., Eden, L., Hitt, M.A. \& Ireland, R.U. 2008. Friends, acquaintances, or strangers? Partner selection in R\&D alliances. Academy of Management Journal, 51(2): 315-334.

Lin, Z., Yang, H. B. \& Demirkan, I. 2007. The performance consequences of ambidexterity in strategic alliance formations: Empirical investigation and computational theorizing. Management Science, 53 (10):1645-1658.

Lin, Z., Yang, H. \& Arya, B. 2009. Alliance partner and firm performance: Resource complementarity and status association. Strategic Management Journal,30(9): 921-940.

March, J.C. \& Simon, H.A. 1958. Organizations. New York, Wiley.

March, J.G. 1991. Exploration and exploitation in organizational learning. Organization Science, 2(1), Special Issue: Organizational Learning: Papers in Honor of (and by) James G. March, $71-87$ 
McMillan, G.S., Narin, F. \& Deeds, D. L. 2000. An analysis of the critical role of public science in innovation: the case of biotechnology. Research Policy, 29(1):1-8.

Menon, T. \& Pfeffer, J. 2003. Valuing internal vs. external knowledge: Explaining the preference for outsiders. Management Science, 49(4): 497-513.

Nelson, R.R. and Winter, S.G. 1982. An evolutionary theory of economic change. Cambridge: Belknap Press.

Ohmae, K. 1985. Triad Power: The coming shape of global competition. Free Press, New York.

Padula, G. 2008. Enhancing the innovation performance of firms by balancing cohesiveness and bridging ties. Long Range Planning, 41(4): 395-411.

Peri, G. 2005. Determinants of Knowledge Flows and Their Effect on Innovation, The Review of Economics and Statistics, MIT Press, vol. 87(2), pages 308-322.

Phelps, C.C (2010). A longitudinal study of the influence of alliance network structure and composition of firm exploratory innovation, The Academy of Management Journal, 53(4), 890-913.

Podolny, J. M.1994. Market uncertainty and the social character of economic exchange. Administrative Science Quarterly, 39: 458-470.

Podolny, J. M. 2001. Network as the pipes and prisms of the market. American Journal of Sociology, 107: 33-60.

Podolny, J. M. \& Stuart, T. E. 1995. A Role-Based Ecology of Technological Change. American Journal of Sociology, vol. 100(5): 1224-1260.

Powell, W.W., Koput, K.W. \& Smith-Doerr, L. 1996. Interorganizational collaboration and the locus of innovation: Network of learning in biotechnology. Administrative Science Quarterly, 41(1): 116-145.

Rosenkopf, L.\& Nerkar, A. 2001. Beyond local search: Boundary-spanning, exploration, and impact in the optical disk industry. Strategic Management Journal, 22: 287-306.

Rosenkopf, L. \& Almeida, P. 2003. Overcoming local search through alliances and mobility. Management Science, 49:751-766.

Rosenkopf, L. \& Padula, G. 2008. Investigating the microstructure of network evolution: Alliance formation in the mobile communications industry. Organization Science, 19: 669-687.

Rosenkopf, L. and McGrath, P. (2011). Advancing the Conceptualization and Operationalization of Novelty in Organizational Research, Organization Science, 22(5), 1297-1311.

Rowley, T. J., Baum, J. A. C., Shipilov, A. V., Greve, H. R. \&Rao, H. 2004. Competing in groups. Managerial and Decision Economics, 25: 453-471.

Rowley, T.J., Greve, H.R., Rao, H., Baum, J.A.C. \& Shipilov, A.V. 2005. Time to break up: social and instrumental antecedents of firm exits from exchange cliques. Academy of Management Journal, 48: 499-520.

Schildt, H., Maula, M.V.J. \& Keil, T. 2005. Explorative and exploitative learning from external corporate ventures. Entrepreneurship Theory and Practice, 29(4): 493-515.

Schilling, M.A. \&Phelps, C. 2007. Interfirm Collaboration Networks: The Impact of Large-scale network structure on Firm Innovation. Management Science 53: 1113-1126.

Schotter, A., Mudambi, R., Doz, Y. and Gaur, A. (2017). Boundary spanning in global organizations. Journal of Management Studies, 54(4): 403-421.

Shipilov, A.V. 2005. Should you bank on your network? Relational and positional embeddedness in the making of financial capital. Strategic Organization, 3:279-309.

Singh, H., Kryscynski, D., Li, X. and Gopal, R. (2015). Pipes, pools and filters: How collaboration networks affect innovative performance. Strategic Management Journal, 37(8), 1649-1666.

Sirén, C.A., Kohtamäki, M. Kuckertz, (2012). Exploration and exploitation strategies, profit performance, and the mediating role of strategic learning: Escaping the exploitation trap, Strategic Entrepreneurship Journal. 6(1), 18-41.

Stettner, U. and Lavie, D. (2013). Ambidexterity under scrutiny: Exploration and exploitation via 
internal organization, alliances, and acquisitions, Strategic Management Journal, 35(13), 1903-1929.

Stuart, T. E., \& Podolny, J.M., 2000. Positional causes and consequences of alliance formation in the semiconductor industry. In: Weesie, J., Raub, W.,(eds), The Management of Durable

Relations: Theoretical Models and Empirical Studies of Households and Organizations, Thelathesis, Amsterdam.

Sytch, M., Tatarynowicz, A. \& Gulati, R. 2012. Toward a Theory of Extended Contact: The Incentives and Opportunities for Bridging Across Network Communities.Organization Science. (In Press)

Tiwana, A. 2007. Do bridging ties complement strong ties? An empirical examination of alliance ambidexterity. Strategic Management Journal, 29(3): 251-272.

Uzzi, B. 1997. Social structure and competition in interfirm networks: The paradox of embeddedness. Administrative Science Quarterly, 42(1): 35-67.

Van de Vrande, V., Lemmens, C. \& Vanhaverbeke, W. 2006. Choosing governance modes for external technology sourcing. R\&D Management, 36(3): 347-363.

Wasserman, S. \& Faust, K. 1994. Social Network Analysis: Methods and Applications. Cambridge

University Press.

Watts, D.J. 1999. Networks, dynamics and the small world phenomenon. American Journal of Sociology, 105:493-527.

Watts, D.J., S.H. Strogatz. 1998. Collective dynamics of "small world" networks. Nature, 393: 440-442.

Weiblen, T. and Chesbrough, H. (2015). Engaging with start-ups to enhance corporate innovation, California Management Review, 57(2), 66-90.

Wiersema, M.F. \& H.P. Bowen. 2008. Corporate diversification: the impact of foreign competition, industry globalization, and product diversification. Strategic Management Journal, 29(2), 115-132.

Zaheer, A. \& Bell, G.G. 2005. Benefiting from network position: Firm capabilities, structural holes, and performance. Strategic Management Journal, 26: 809-825.

\section{TABLE 1}

\section{ASIC definitions}

I. Semicustom IC: A monolithic circuit that has one or more customised mask layers, but does not have all mask layers customised, and is sold to only one customer.

Gate arrays: A monolithic IC usually composed of columns and rows of transistors. One or more layers of metal interconnect and are used to customise the chip.

Linear array: An array of transistors and resistors that performs the functions of several linear ICs and discrete devices.

II. Custom IC:A monolithic circuit that is customised on all mask layers and is sold to only one customer. Standard cell IC: A monolithic circuit that is customised on all mask layers using a cell library that embodies pre-characterised circuit structures. 
Full custom IC: A monolithic circuit that is at least partially "handcrafted". Handcrafting refers to custom layout and connection work that is accomplished without the aid of standard cells.

III. Programmable Logic Device (PLD): A monolithic circuit with fuse, antifuse, or memory cell-based logic that may be programmed (customised), and in some cases, reprogrammed by the user.

Field Programmable Gate Array (FPGA): A PLD that offers fully flexible interconnects, fully flexible logic arrays, and requires functional placement and routing.

Electrically Programmable Analog Circuit (EPAC): A PLD that allows the user to program and reprogram basic analog devices

FIGURE 1

\section{Firms in the ASIC Industry}

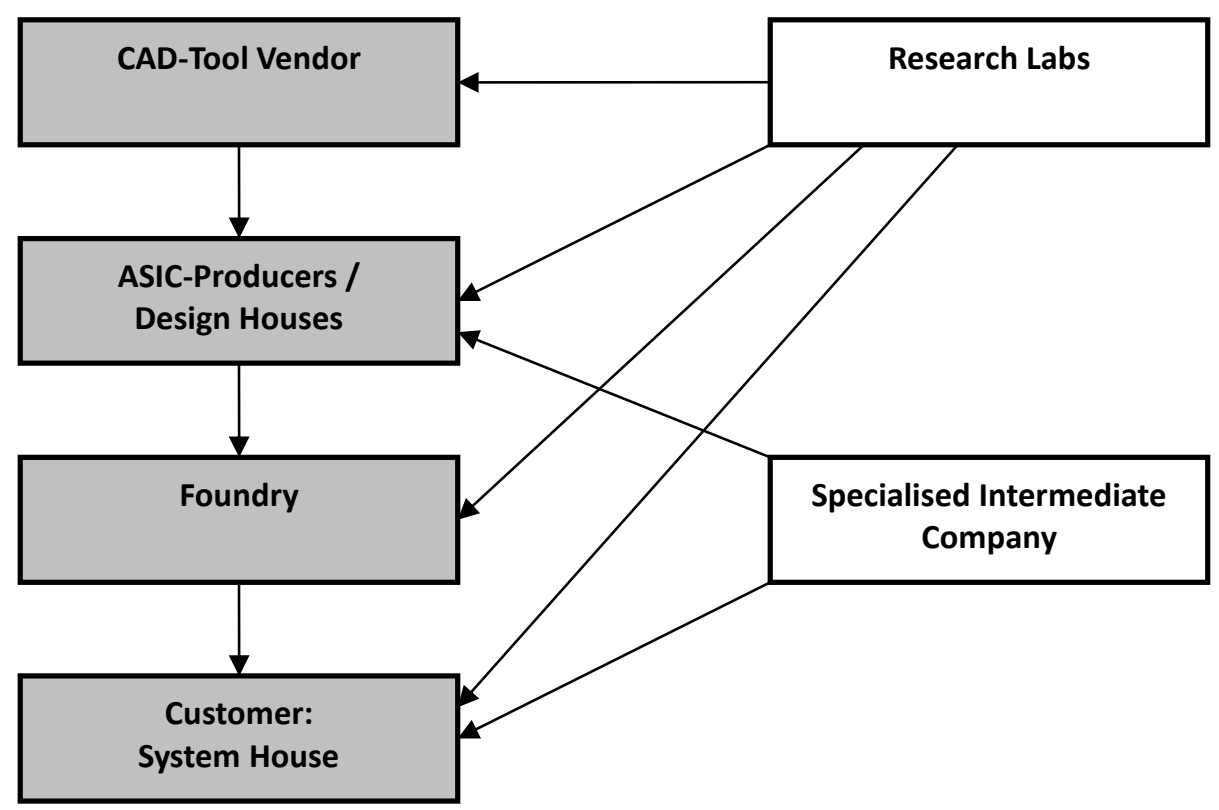


FIGURE 2.

How to distinguish between the two types of explorative learning

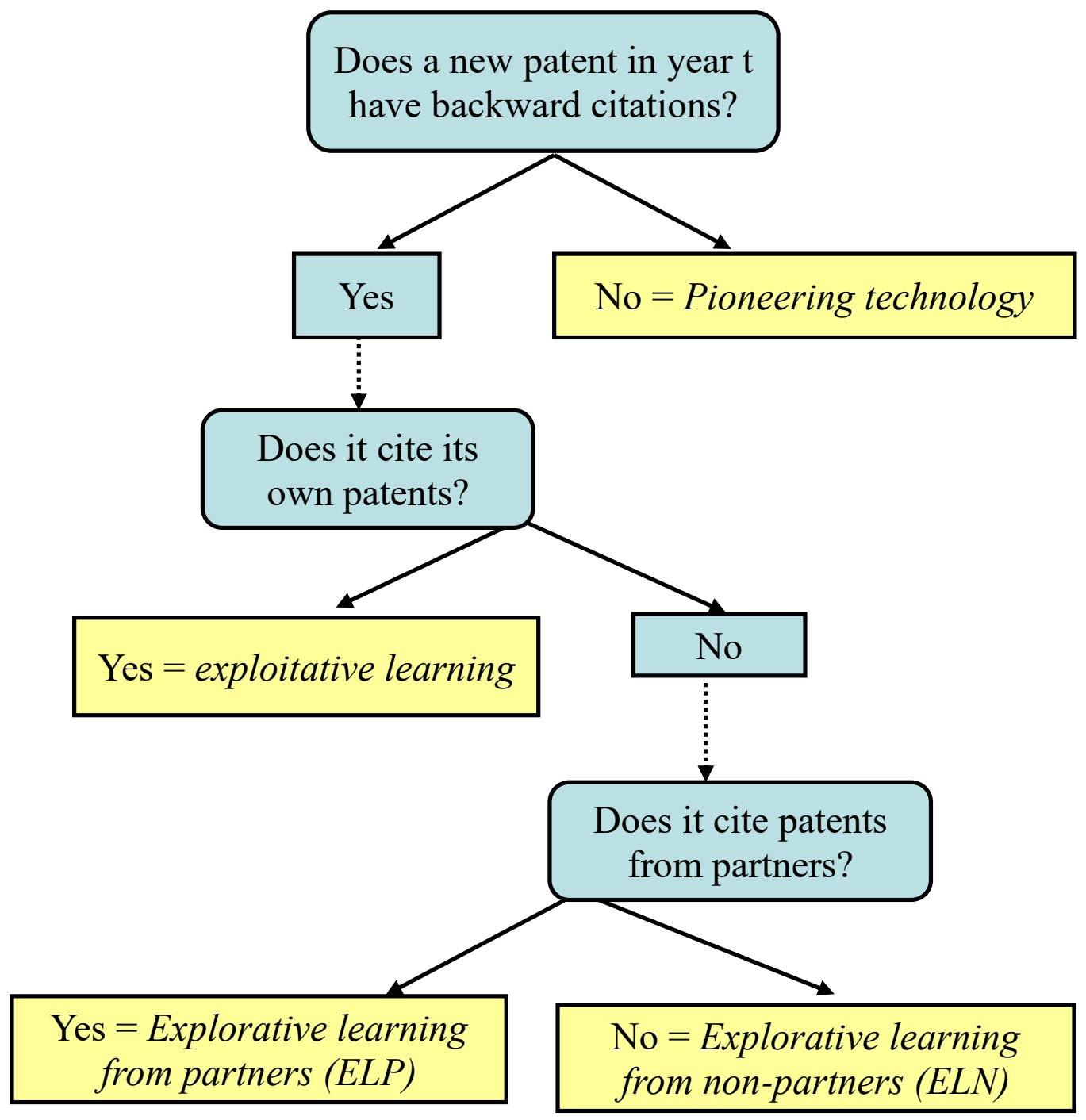


TABLE 2

\section{Definitions of dependent and independent variables}

\begin{tabular}{|c|c|}
\hline Variable name & Variable description \\
\hline Explorative learning from partners (ELP) & $\begin{array}{l}\text { The number of patents successfully applied for in year } \mathrm{t} \text { by the focal firm, which have at least one } \\
\text { backward citation to its alliance partners' prior patents, but no citations to its own prior patents }\end{array}$ \\
\hline Explorative learning from non-partners (ELN) & $\begin{array}{l}\text { The number of patents successfully applied for in year } t \text { by the focal firm, which neither cites its } \\
\text { own prior patents nor its alliance partners' prior patents. }\end{array}$ \\
\hline Prior Clique Spanning Ties (CST) & $\begin{array}{l}\text { Alliances linking two firms belonging to two different alliance cliques using the prior alliance } \\
\text { network in the ASIC industry (t-1 to t-5) }\end{array}$ \\
\hline Prior Outside ties (OT) & $\begin{array}{l}\text { Alliances linking a firm belonging to an alliance clique with one that is not a clique member } \\
\text { using the prior alliance network in the ASIC industry (t-1 to t-5) }\end{array}$ \\
\hline Prior Inside ties (IT) & $\begin{array}{l}\text { Alliances linking two firms belonging to the same alliance clique - using the prior alliance } \\
\text { network in the ASIC industry(t-1 to t-5) }\end{array}$ \\
\hline Technological Capital & Count variable indicating the number of successful patent applications in $(t-1$ to $t-5)$ \\
\hline Technological distance & Distance between technology portfolio of the focal firms and that of its partners ( $t-1$ to $t-5)$ \\
\hline Firm Size & Total overall sales of the focal firm/1000 (t-1) \\
\hline Firm R\&D to sales ratio & Firm total R\&D expenditures / Firm overall sales (t-1) \\
\hline Firm is Captive producer & Dummy variable denoting that the firm is not selling products on the ASICmarket \\
\hline Firm is SCProducer & Dummy variable denoting that the firm is only producing Standard Cells \\
\hline Firm is PLD Producer & Dummy variable denoting that the firm is only producing PLDs \\
\hline Firm is GAandSCProducer & Dummy variable denoting that the firm is only producing Gate Arrays and Standard Cells \\
\hline Firm is GAandPLDProducer & Dummy variable denoting that the firm is only producing Gate Arrays and PLDs \\
\hline Firm is SCandPLDProducer & Dummy variable denoting that the firm is only producing Standard Cells and PLDs \\
\hline Firm is GAandSCandPLDProducer & Dummy variable denoting that the firm is producing Gate Arrays and Standard Cells and PLDs \\
\hline Firm is European & Dummy variable denoting that the firm is headquartered in Europe \\
\hline Firm is Asian & Dummy variable denoting that the firm is headquartered in Asia \\
\hline Dummy 1987-1999 & Dummy variable denoting the year of observation \\
\hline
\end{tabular}


TABLE 3: Descriptive statistics of the variables

\begin{tabular}{llcll} 
Variable & Mean & Std. Dev. & Min & Max \\
\hline ELP & .8724728 & 1.515004 & 0 & 12 \\
ELN & .785381 & 1.741192 & 0 & 22 \\
CST & 1.07465 & 1.193451 & 0 & 8 \\
OT & .4883359 & .8562238 & 0 & 5 \\
IT & 1.289269 & 1.913306 & 0 & 9 \\
CST*techn.capital & 21.3717 & 55.29155 & 0 & 736 \\
OT*techn.capital & 6.953344 & 27.47388 & 0 & 388 \\
IT*techn.capital & 19.58165 & 44.68377 & 0 & 552 \\
Techn. capital & 12.83826 & 25.24217 & 0 & 307 \\
Ln(totalsales) & 7.838465 & 2.703919 & 0.2 & 12.01 \\
(rd / sales) & .1056143 & .0696322 & .01 & .67 \\
Captive & .1679627 & .3741242 & 0 & 1 \\
Dga & .0824261 & .2752269 & 0 & 1 \\
Dsc & 2130638 & .4097911 & 0 & 1 \\
Dgasc & .4245723 & .4946627 & 0 & 1 \\
Dscpld & .0124417 & .1109325 & 0 & 1 \\
Dgapld & .0217729 & .146055 & 0 & 1 \\
Dgascpld & .1290824 & .3355522 & 0 & 1 \\
European firm & .1804044 & .3848232 & 0 & 1 \\
Asian firm & .251944 & .4344672 & 0 & 1 \\
year 87 & .0637636 & .2445216 & 0 & 1 \\
year 88 & .0653188 & .2472799 & 0 & 1 \\
year 89 & .0715397 & .2579248 & 0 & 1 \\
year 90 & .0699844 & .2553194 & 0 & 1 \\
year 91 & .0684292 & .2526776 & 0 & 1 \\
year 92 & .0777605 & .2680028 & 0 & 1 \\
year 93 & .0762053 & .2655329 & 0 & 1 \\
year 94 & .0762053 & .2655329 & 0 & 1 \\
year 95 & .0793157 & .2704413 & 0 & 1 \\
year 96 & .0762053 & .2655329 & 0 & 1 \\
year 97 & .0699844 & .2553194 & 0 & 1 \\
year 98 & .0715397 & .2579248 & 0 & 1 \\
year 99 & .0730949 & .2604948 & 0 & 1 \\
---------------------------------------------------------------------- \\
\end{tabular}

Number of observations $=643$ 
TABLE 4: Cross correlation table

\begin{tabular}{|c|c|c|c|c|c|c|}
\hline & ELP & ELN & PCT & OT & IT & \\
\hline ELP & 1.0000 & & & & & \\
\hline ELN & 0.3793 & 1.0000 & & & & \\
\hline PCT & 0.3369 & 0.1014 & 1.0000 & & & \\
\hline OT & 0.0565 & 0.0129 & -0.0022 & 1.0000 & & \\
\hline IT & 0.2169 & -0.0234 & 0.4523 & 0.0895 & 1.000 & \\
\hline Tcap & 0.4238 & 0.6412 & 0.2518 & 0.0317 & 0.0628 & \\
\hline $\ln$ (sales) & 0.1635 & 0.0623 & 0.2622 & 0.0777 & 0.2481 & \\
\hline $\mathrm{rd} / \mathrm{sales}$ & -0.0402 & -0.0354 & -0.0738 & 0.0004 & -0.0674 & \\
\hline captive & -0.0831 & -0.0833 & -0.0735 & -0.0863 & -0.0789 & \\
\hline dga & -0.1279 & -0.0963 & -0.1990 & -0.0653 & -0.1725 & \\
\hline $\mathrm{dsc}$ & -0.1293 & -0.1410 & -0.1440 & -0.0351 & -0.1522 & \\
\hline dgasc & -0.0752 & -0.0044 & 0.0729 & -0.0159 & 0.0083 & \\
\hline dscpld & 0.0373 & -0.0184 & 0.0989 & 0.0015 & 0.1371 & \\
\hline dgapld & 0.1111 & 0.0184 & -0.0004 & 0.1764 & 0.0499 & \\
\hline dgascpld & 0.1213 & -0.0245 & 0.2559 & 0.1381 & 0.3469 & \\
\hline Eur firm & -0.0780 & -0.1444 & 0.0554 & 0.1766 & 0.3944 & \\
\hline Asia firm & -0.0268 & 0.1025 & -0.0544 & -0.0716 & -0.1328 & \\
\hline year 87 & -0.0705 & -0.0593 & -0.1231 & 0.0891 & -0.0428 & \\
\hline year 88 & -0.0734 & -0.0506 & -0.0746 & 0.1287 & 0.0094 & \\
\hline year 89 & 0.0205 & -0.0282 & -0.0528 & 0.1237 & 0.0338 & \\
\hline year 90 & -0.0212 & -0.0187 & -0.0325 & 0.0999 & 0.0286 & \\
\hline year 91 & -0.0138 & -0.0374 & -0.0325 & 0.0541 & 0.0299 & \\
\hline year 92 & -0.0561 & -0.0677 & 0.0208 & -0.0096 & -0.0105 & \\
\hline year 93 & 0.0010 & -0.0151 & 0.0312 & -0.0543 & 0.0301 & \\
\hline year 94 & -0.0261 & -0.0185 & 0.0361 & -0.0749 & 0.0025 & \\
\hline year 95 & 0.0589 & 0.0064 & 0.0444 & -0.0666 & 0.0218 & \\
\hline year 96 & 0.0513 & -0.0084 & 0.0902 & -0.0680 & 0.0332 & \\
\hline year 97 & 0.0473 & 0.0479 & 0.0237 & -0.0924 & 0.0223 & \\
\hline year 98 & 0.0353 & 0.0585 & -0.0073 & -0.0385 & -0.0546 & \\
\hline \multirow[t]{2}{*}{ year 99} & 0.0070 & 0.0896 & 0.0425 & 0.0346 & -0.0644 & \\
\hline & cap & $\ln$ (sales) & $\mathrm{rd} / \mathrm{sales}$ & captive & dga & dsc \\
\hline tcap & 1.0000 & & & & & \\
\hline $\ln$ (sales) & 0.0598 & 1.0000 & & & & \\
\hline $\mathrm{rd} / \mathrm{sales}$ & 0.0216 & -0.6798 & 1.0000 & & & \\
\hline captive & -0.1347 & 0.3174 & -0.1887 & 1.0000 & & \\
\hline dga & -0.1328 & -0.2158 & 0.1262 & -0.0590 & 1.0000 & \\
\hline $\mathrm{dsc}$ & -0.1609 & -0.1584 & 0.1371 & 0.2234 & -0.1560 & 1.0000 \\
\hline dgasc & -0.0789 & 0.4112 & -0.3673 & 0.1022 & -0.2574 & -0.4470 \\
\hline dscpld & -0.0204 & 0.0130 & 0.0353 & -0.0504 & -0.0336 & -0.0584 \\
\hline dgapld & 0.0571 & 0.0262 & 0.0599 & -0.0670 & -0.0447 & -0.0776 \\
\hline dgascpld & 0.0236 & 0.1714 & -0.1044 & -0.1730 & -0.1154 & -0.2003 \\
\hline Eur firm & -0.1578 & 0.1240 & -0.0082 & 0.1462 & -0.0965 & 0.1115 \\
\hline Asia firm & -0.0216 & 0.4075 & -0.4062 & -0.1266 & -0.0437 & -0.2495 \\
\hline year 87 & -0.0993 & -0.0479 & 0.0018 & 0.0360 & -0.0088 & 0.0197 \\
\hline year 88 & -0.0944 & -0.0864 & 0.0845 & 0.0159 & 0.0123 & -0.0300 \\
\hline year 89 & -0.0827 & -0.0472 & 0.0158 & -0.0117 & 0.0485 & -0.0118 \\
\hline year 90 & -0.0681 & -0.0528 & 0.0252 & -0.0254 & 0.0064 & -0.0088 \\
\hline year 91 & -0.0491 & -0.0246 & 0.0419 & -0.0064 & -0.0140 & -0.0207 \\
\hline year 92 & -0.0506 & -0.0145 & 0.0425 & 0.0093 & -0.0026 & 0.0049 \\
\hline year 93 & -0.0321 & 0.0162 & -0.0206 & 0.0277 & 0.0205 & -0.0206 \\
\hline year 94 & -0.0193 & 0.0155 & -0.0206 & 0.0277 & -0.0221 & 0.0080 \\
\hline year 95 & -0.0093 & 0.0176 & -0.0303 & 0.0067 & -0.0461 & -0.0122 \\
\hline year 96 & 0.0337 & 0.0537 & -0.0653 & 0.0277 & 0.0435 & 0.0080 \\
\hline year 97 & 0.0646 & 0.0538 & -0.0537 & 0.0072 & -0.0157 & -0.0088 \\
\hline year 98 & 0.1197 & 0.0164 & -0.0077 & -0.0440 & 0.0265 & 0.0029 \\
\hline year 99 & 0.0987 & 0.0330 & 0.0074 & -0.0463 & 0.0245 & 0.0144 \\
\hline
\end{tabular}




\begin{tabular}{|c|c|c|c|c|c|c|c|}
\hline & dgasc & dscpld & dgapld & dgascpld & Eur firm & Asia firm & year 87 \\
\hline dgasc & 1.0000 & & & & & & \\
\hline dscpld & -0.0964 & 1.0000 & & & & & \\
\hline dgapld & -0.1282 & -0.0167 & 1.0000 & & & & \\
\hline dgascpld & -0.3307 & -0.0432 & -0.0574 & 1.0000 & & & \\
\hline Eur firm & 0.0061 & -0.0527 & 0.0963 & 0.0727 & 1.0000 & & \\
\hline Asia firm & 0.4727 & -0.0651 & -0.0866 & -0.0952 & -0.2723 & 1.0000 & \\
\hline year 87 & -0.0052 & 0.0281 & 0.0483 & -0.0056 & 0.0100 & -0.0635 & 1.0000 \\
\hline year 88 & 0.0021 & 0.0271 & 0.0037 & 0.0109 & 0.0233 & -0.0664 & -0.0690 \\
\hline year 89 & -0.0065 & 0.0233 & -0.0001 & 0.0011 & -0.0047 & 0.0057 & -0.0724 \\
\hline year 90 & -0.0136 & 0.0242 & 0.0008 & 0.0217 & -0.0177 & -0.0047 & -0.0716 \\
\hline year 91 & 0.0040 & 0.0251 & 0.0018 & 0.0243 & 0.0010 & -0.0154 & -0.0707 \\
\hline year 92 & -0.0144 & 0.0198 & 0.0363 & 0.0268 & -0.0154 & 0.0054 & -0.0758 \\
\hline year 93 & -0.0095 & 0.0206 & -0.0027 & 0.0468 & 0.0177 & 0.0088 & -0.0750 \\
\hline year 94 & -0.0095 & 0.0206 & -0.0428 & 0.0468 & 0.0177 & -0.0047 & -0.0750 \\
\hline year 95 & 0.0157 & -0.0329 & -0.0438 & 0.0243 & 0.0120 & 0.0020 & -0.0766 \\
\hline year 96 & 0.0260 & -0.0322 & -0.0027 & -0.0232 & 0.0024 & -0.0047 & -0.0750 \\
\hline year 97 & 0.0234 & -0.0308 & 0.0008 & -0.0329 & -0.0019 & -0.0047 & -0.0716 \\
\hline year 98 & -0.0065 & -0.0312 & -0.0001 & -0.0529 & -0.0361 & 0.0196 & -0.0724 \\
\hline \multirow[t]{2}{*}{ year 99} & 0.0005 & -0.0315 & -0.0010 & -0.0547 & -0.0074 & 0.0572 & -0.0733 \\
\hline & year 88 & year 89 & year 90 & year 91 & year 92 & year 93 & year 94 \\
\hline year 88 & 1.0000 & & & & & & \\
\hline year 89 & -0.0734 & 1.0000 & & & & & \\
\hline year 90 & -0.0725 & -0.0761 & 1.0000 & & & & \\
\hline year 91 & -0.0716 & -0.0752 & -0.0743 & 1.0000 & & & \\
\hline year 92 & -0.0768 & -0.0806 & -0.0797 & -0.0787 & 1.0000 & & \\
\hline year 93 & -0.0759 & -0.0797 & -0.0788 & -0.0778 & -0.0834 & 1.0000 & \\
\hline year 94 & -0.0759 & -0.0797 & -0.0788 & -0.0778 & -0.0834 & -0.0825 & 1.0000 \\
\hline year 95 & -0.0776 & -0.0815 & -0.0805 & -0.0795 & -0.0852 & -0.0843 & -0.0843 \\
\hline year 96 & -0.0759 & -0.0797 & -0.0788 & -0.0778 & -0.0834 & -0.0825 & -0.0825 \\
\hline year 97 & -0.0725 & -0.0761 & -0.0753 & -0.0743 & -0.0797 & -0.0788 & -0.0788 \\
\hline year 98 & -0.0734 & -0.0771 & -0.0761 & -0.0752 & -0.0806 & -0.0797 & -0.0797 \\
\hline \multirow[t]{2}{*}{ year 99} & -0.0742 & -0.0780 & -0.0770 & -0.0761 & -0.0815 & -0.0807 & -0.0807 \\
\hline & year 95 & year 96 & year 97 & year 98 & year 99 & & \\
\hline year 95 & 1.0000 & & & & & & \\
\hline year 96 & -0.0843 & 1.0000 & & & & & \\
\hline year 97 & -0.0805 & -0.0788 & 1.0000 & & & & \\
\hline year 98 & -0.0815 & -0.0797 & -0.0761 & 1.0000 & & & \\
\hline year 99 & -0.0824 & -0.0807 & -0.0770 & -0.0780 & 1.0000 & & \\
\hline
\end{tabular}

Number of observations: 643 
TABLE 5: Random effects panel estimation results for both types of explorative learning

\begin{tabular}{|c|c|c|c|c|c|c|c|c|c|c|c|c|}
\hline & \multicolumn{6}{|c|}{ Exploration from partners (ELP) } & \multicolumn{6}{|c|}{ Exploration from non-partners (ELN) } \\
\hline & (1) & $(2)$ & (3) & $(4)$ & $(5)$ & $(6)$ & $(7)$ & $(8)$ & (9) & $(10)$ & (11) & $(12)$ \\
\hline Clique-spanning ties (CST) & & $\begin{array}{l}0.149 * * * \\
(0.049)\end{array}$ & $\begin{array}{l}0.316^{* * * *} \\
(0.069)\end{array}$ & & & $\begin{array}{l}0.239 * * * \\
(0.077)\end{array}$ & & $\begin{array}{l}0.083 \\
(0.058)\end{array}$ & $\begin{array}{l}0.115 \\
(0.078)\end{array}$ & & & $\begin{array}{l}0.095 \\
(0.086)\end{array}$ \\
\hline CST $*$ techn. capital & & & $\begin{array}{l}-0.004 * * * \\
(0.001)\end{array}$ & & & $\begin{array}{l}-0.001 \\
(0.002)\end{array}$ & & & $\begin{array}{l}-0.001 \\
(0.002)\end{array}$ & & & $\begin{array}{l}0.003 \\
(0.002)\end{array}$ \\
\hline Outside ties (OT) & & $\begin{array}{l}0.054 \\
(0.078)\end{array}$ & & $\begin{array}{l}0.177 * \\
(0.097)\end{array}$ & & $\begin{array}{l}0.226 * * \\
(0.097)\end{array}$ & & $\begin{array}{l}0.158^{*} \\
(0.086)\end{array}$ & & $\begin{array}{l}0.204 * * \\
(0.098)\end{array}$ & & $\begin{array}{l}0.252 * * \\
(0.101)\end{array}$ \\
\hline OT $*$ techn. capital & & & & $\begin{array}{l}-0.003^{*} \\
(0.002)\end{array}$ & & $\begin{array}{l}-0.004 * * \\
(0.002)\end{array}$ & & & & $\begin{array}{l}-0.002 \\
(0.002)\end{array}$ & & $\begin{array}{l}-0.003 \\
(0.002)\end{array}$ \\
\hline Inside ties (IT) & & $\begin{array}{l}0.006 \\
(0.044)\end{array}$ & & & $\begin{array}{l}0.103 * * \\
(0.051)\end{array}$ & $\begin{array}{l}0.109 * \\
(0.056)\end{array}$ & & $\begin{array}{l}0.033 \\
(0.052)\end{array}$ & & & $\begin{array}{l}0.059 \\
(0.062)\end{array}$ & $\begin{array}{l}0.077 \\
(0.070)\end{array}$ \\
\hline IT $*$ techn. capital & & & & & $\begin{array}{l}-0.003^{*} \\
(0.001)\end{array}$ & $\begin{array}{l}-0.005 * * \\
(0.002)\end{array}$ & & & & & $\begin{array}{l}-0.001 \\
(0.002)\end{array}$ & $\begin{array}{l}-0.002 \\
(0.002)\end{array}$ \\
\hline Technological Capital/100 & & $\begin{array}{l}-0.091 \\
(0.188)\end{array}$ & $\begin{array}{l}0.385^{*} \\
(0.229)\end{array}$ & $\begin{array}{l}0.065 \\
(0.192)\end{array}$ & $\begin{array}{l}0.116 \\
(0.192)\end{array}$ & $\begin{array}{l}0.443 * \\
(0.243)\end{array}$ & & $\begin{array}{l}0.575 * * * \\
(0.153)\end{array}$ & $\begin{array}{l}0.6798 * * * \\
(0.236)\end{array}$ & $\begin{array}{l}0.662 * * * \\
(0.160)\end{array}$ & $\begin{array}{l}0.671 * * * \\
(0.197)\end{array}$ & $\begin{array}{l}0.801 * * * \\
(0.250)\end{array}$ \\
\hline Firm Size & $\begin{array}{l}0.419 * * * \\
(0.082)\end{array}$ & $\begin{array}{l}0.3474 * * * \\
(0.084)\end{array}$ & $\begin{array}{l}0.373 * * * \\
(0.081)\end{array}$ & $\begin{array}{l}0.421 * * * \\
(0.086)\end{array}$ & $\begin{array}{l}0.411 * * * \\
(0.085)\end{array}$ & $\begin{array}{l}0.356 * * * \\
(0.082)\end{array}$ & $\begin{array}{l}0.355 * * * \\
(0.072)\end{array}$ & $\begin{array}{l}0.259 * * * \\
(0.072)\end{array}$ & $\begin{array}{l}0.260 * * * \\
(0.071)\end{array}$ & $\begin{array}{l}0.273 * * * \\
(0.071)\end{array}$ & $\begin{array}{l}0.268 * * * \\
(0.070)\end{array}$ & $\begin{array}{l}0.248 * * * \\
(0.072)\end{array}$ \\
\hline $\mathrm{R} \& \mathrm{D}$ Intensity & $\begin{array}{l}-2.017 \\
(2.092)\end{array}$ & $\begin{array}{l}-1.266 \\
(2.030)\end{array}$ & $\begin{array}{l}-2.087 \\
(2.092)\end{array}$ & $\begin{array}{l}-2.644 \\
(2.167)\end{array}$ & $\begin{array}{l}-2.151 \\
(2.111)\end{array}$ & $\begin{array}{l}-2.353 \\
(2.127)\end{array}$ & $\begin{array}{l}0.554 \\
(1.917)\end{array}$ & $\begin{array}{l}0.486 \\
(1.892)\end{array}$ & $\begin{array}{l}0.169 \\
(1.914)\end{array}$ & $\begin{array}{l}0.244 \\
(1.950)\end{array}$ & $\begin{array}{l}0.467 \\
(1.885)\end{array}$ & $\begin{array}{l}0.078 \\
(1.977)\end{array}$ \\
\hline Captive Producer & $\begin{array}{l}-0.757 * * \\
(0.308)\end{array}$ & $\begin{array}{l}-0.408 \\
(0.327)\end{array}$ & $\begin{array}{l}-0.624 * \\
(0.314)\end{array}$ & $\begin{array}{l}-0.747 * * \\
(0.309)\end{array}$ & $\begin{array}{l}-0.887 * * * \\
(0.314)\end{array}$ & $\begin{array}{l}-0.597 * \\
(0.313)\end{array}$ & $\begin{array}{l}-0.627 * \\
(0.338)\end{array}$ & $\begin{array}{l}-0.392 \\
(0.356)\end{array}$ & $\begin{array}{l}-0.449 \\
(0.327)\end{array}$ & $\begin{array}{l}-0.490 \\
(0.323)\end{array}$ & $\begin{array}{l}-0.496 \\
(0.323)\end{array}$ & $\begin{array}{l}-0.387 \\
(0.324)\end{array}$ \\
\hline GAProducer & $\begin{array}{l}-1.230 * \\
(0.654)\end{array}$ & $\begin{array}{l}-1.540^{* *} \\
(0.641)\end{array}$ & $\begin{array}{l}-1.588 * * * \\
(0.611)\end{array}$ & $\begin{array}{l}-1.329 * \\
(0.685)\end{array}$ & $\begin{array}{l}-1.381 * * \\
(0.527)\end{array}$ & $\begin{array}{l}-1.714 * * * \\
(0.637)\end{array}$ & $\begin{array}{l}-2.407 * * * \\
(0.538)\end{array}$ & $\begin{array}{l}-2.139 * * * \\
(0.530)\end{array}$ & $\begin{array}{l}-2.049 * * * \\
(0.521)\end{array}$ & $\begin{array}{l}-2.166^{* * *} \\
(0.535)\end{array}$ & $\begin{array}{l}-2.044 * * * \\
(0.521)\end{array}$ & $\begin{array}{l}-2175 * * * \\
(0.532)\end{array}$ \\
\hline SCProducer & $\begin{array}{l}-2.151 * * * \\
(0.516)\end{array}$ & $\begin{array}{l}-2.460 * * * \\
(0.425)\end{array}$ & $\begin{array}{l}-2.286 * * * \\
(0.500)\end{array}$ & $\begin{array}{l}-2.220 * * * \\
(0.536)\end{array}$ & $\begin{array}{l}-2.158 * * * \\
(0.527)\end{array}$ & $\begin{array}{l}-2.358 * * * \\
(0.508)\end{array}$ & $\begin{array}{l}-2.367 * * * \\
(0.453)\end{array}$ & $\begin{array}{l}-2.075 * * * \\
(0.446)\end{array}$ & $\begin{array}{l}-2.015 * * * \\
(0.443)\end{array}$ & $\begin{array}{l}-2.060 * * * \\
(0.444)\end{array}$ & $\begin{array}{l}1.979 * * * \\
(0.440)\end{array}$ & $\begin{array}{l}-2.032 * * * \\
(0.443)\end{array}$ \\
\hline GA and SCProducer & $\begin{array}{l}-1.810 * * * \\
(0.414)\end{array}$ & $\begin{array}{l}-2.020 * * * \\
(0.425)\end{array}$ & $\begin{array}{l}-2.155 * * * \\
(0.427)\end{array}$ & $\begin{array}{l}-1.926 * * * \\
(0.440)\end{array}$ & $\begin{array}{l}-1.984 * * * \\
(0.439)\end{array}$ & $\begin{array}{l}-2.332 * * * \\
(0.444)\end{array}$ & $\begin{array}{l}-2.336^{* * * *} \\
(0.415)\end{array}$ & $\begin{array}{l}-2.085^{* * *} \\
(0.412)\end{array}$ & $\begin{array}{l}-2.036 * * * \\
(0.408)\end{array}$ & $\begin{array}{l}-2.025 * * * \\
(0.408)\end{array}$ & $\begin{array}{l}-1.984 * * * \\
(0.404)\end{array}$ & $\begin{array}{l}-2.114 * * * \\
(0.412)\end{array}$ \\
\hline SC and PLDProducer & $\begin{array}{l}-2.593 * * * \\
(0.669)\end{array}$ & $\begin{array}{l}-2.411 * * * \\
(0.688)\end{array}$ & $\begin{array}{l}-2.650 * * * \\
(0.683)\end{array}$ & $\begin{array}{l}-2.741 * * * \\
(0.689)\end{array}$ & $\begin{array}{l}-3.028 * * * \\
(0.707)\end{array}$ & $\begin{array}{l}-2.972 * * * \\
(0.710)\end{array}$ & $\begin{array}{l}-1.868 * \\
(1.004)\end{array}$ & $\begin{array}{l}-1.670 * \\
(0.993)\end{array}$ & $\begin{array}{l}-1.563 \\
(0.977)\end{array}$ & $\begin{array}{l}-1.571 \\
(0.965)\end{array}$ & $\begin{array}{l}-1.798 * \\
(1.005)\end{array}$ & $\begin{array}{l}-1.757 * \\
(0.993)\end{array}$ \\
\hline GA and PLDProducer & $\begin{array}{l}-0.388 \\
(0.350)\end{array}$ & $\begin{array}{l}-0.460 \\
(0.384)\end{array}$ & $\begin{array}{l}-0.329 \\
(0.345)\end{array}$ & $\begin{array}{l}-0.541 \\
(0.387)\end{array}$ & $\begin{array}{l}-0.288 \\
(0.352)\end{array}$ & $\begin{array}{l}-0.335 \\
(0.392)\end{array}$ & $\begin{array}{l}-0.985^{* *} \\
(0.455)\end{array}$ & $\begin{array}{l}-1.079 * * \\
(0.470)\end{array}$ & $\begin{array}{l}-0.766^{*} \\
(0.430)\end{array}$ & $\begin{array}{l}-1.012 * * \\
(0.467)\end{array}$ & $\begin{array}{l}-0.750 * \\
(0.446)\end{array}$ & $\begin{array}{l}-0.936^{*} \\
(0.480)\end{array}$ \\
\hline GA, SC and PLDProducer & $\begin{array}{l}-1.633 * * * \\
(0.429)\end{array}$ & $\begin{array}{l}-1.845^{* * *} \\
(0.440)\end{array}$ & $\begin{array}{l}-1.964 * * * \\
(0.433)\end{array}$ & $\begin{array}{l}-1.779 * * * \\
(0.453)\end{array}$ & $\begin{array}{l}-1.760 * * * \\
(0.446)\end{array}$ & $\begin{array}{l}-2.083 * * * \\
(0.457)\end{array}$ & $\begin{array}{l}-1.930 * * * \\
(0.430)\end{array}$ & $\begin{array}{l}-1.833 * * * \\
(0.445)\end{array}$ & $\begin{array}{l}-1.684 * * * \\
(0.430)\end{array}$ & $\begin{array}{l}-1.716^{* * *} \\
(0.433)\end{array}$ & $\begin{array}{l}-1.678 * * * \\
(0.435)\end{array}$ & $\begin{array}{l}-1.843 * * * \\
(0.448)\end{array}$ \\
\hline
\end{tabular}




\begin{tabular}{|c|c|c|c|c|c|c|c|c|c|c|c|c|}
\hline Firm is European & $\begin{array}{l}-0.621 \\
(0.441)\end{array}$ & $\begin{array}{l}-0.533 \\
(0.427)\end{array}$ & $\begin{array}{l}-0.547 \\
(0.419)\end{array}$ & $\begin{array}{l}-0.716 \\
(0.453)\end{array}$ & $\begin{array}{l}-0.794 * \\
(0.452)\end{array}$ & $\begin{array}{l}-0.795^{*} \\
(0.444)\end{array}$ & $\begin{array}{l}-0.824 * * \\
(0.330)\end{array}$ & $\begin{array}{l}-0.850 * * \\
(0.386)\end{array}$ & $\begin{array}{l}-0.726 * * \\
(0.368)\end{array}$ & $\begin{array}{l}-0.834 * * \\
(0.316)\end{array}$ & $\begin{array}{l}-0.847 * * \\
(0.386)\end{array}$ & $\begin{array}{l}-1.0010 * * \\
(0.399)\end{array}$ \\
\hline Firm is Asian & $\begin{array}{l}-0.617 \\
(0.420)\end{array}$ & $\begin{array}{l}-0.370 \\
(0.400)\end{array}$ & $\begin{array}{l}-0.430 \\
(0.391)\end{array}$ & $\begin{array}{l}-0.670 \\
(0.433)\end{array}$ & $\begin{array}{l}-0.578 \\
(0.425)\end{array}$ & $\begin{array}{l}-0.382 \\
(0.399)\end{array}$ & $\begin{array}{l}0.375 \\
(0.330)\end{array}$ & $\begin{array}{l}0.617^{*} \\
(0.318)\end{array}$ & $\begin{array}{l}0.572 * \\
(0.316)\end{array}$ & $\begin{array}{l}0.499 \\
(0.316)\end{array}$ & $\begin{array}{l}0.552^{*} \\
(0.314)\end{array}$ & $\begin{array}{l}0.627 * * \\
(0.317)\end{array}$ \\
\hline Constant & $\begin{array}{l}-0.200 \\
(0.912)\end{array}$ & $\begin{array}{l}-0.206 \\
(0.886)\end{array}$ & $\begin{array}{l}0.683 \\
(0.907)\end{array}$ & $\begin{array}{l}0.036 \\
(0.942)\end{array}$ & $\begin{array}{l}0.158 \\
(0.942)\end{array}$ & $\begin{array}{l}0.577 \\
(0.948)\end{array}$ & $\begin{array}{l}-0.512 \\
(0.730)\end{array}$ & $\begin{array}{l}-0.539 \\
(0.741)\end{array}$ & $\begin{array}{l}-0.560 \\
(0.847)\end{array}$ & $\begin{array}{l}-0.548 \\
(0.748)\end{array}$ & $\begin{array}{l}-0.610 \\
(0.734)\end{array}$ & $\begin{array}{l}-0.451 \\
(0.745)\end{array}$ \\
\hline Observations (firms) & $643(80)$ & $643(80)$ & $643(80)$ & $643(80)$ & $643(80)$ & $643(80)$ & $643(80)$ & $643(80)$ & $643(80)$ & $643(80)$ & $643(80)$ & $643(80)$ \\
\hline Log Likelihood & -677.2 & -671.6 & -666.9 & -675.2 & -674.3 & -662.1 & -636.0 & -625.8 & -627.5 & -626.7 & -628.3 & -624.3 .3 \\
\hline
\end{tabular}

Table shows results of random effects negative binomial model

Note 1: *** $p<0.01 ; * * p<0.05 ; * p<0.10$

Note 2: Standard Deviations in Parentheses

Note 3: Year dummy variables are included in the regressions but are not reported. 
FIGURE 3: Combined effect of the three types of alliances and technological capital on ELP

Cross-spanning ties

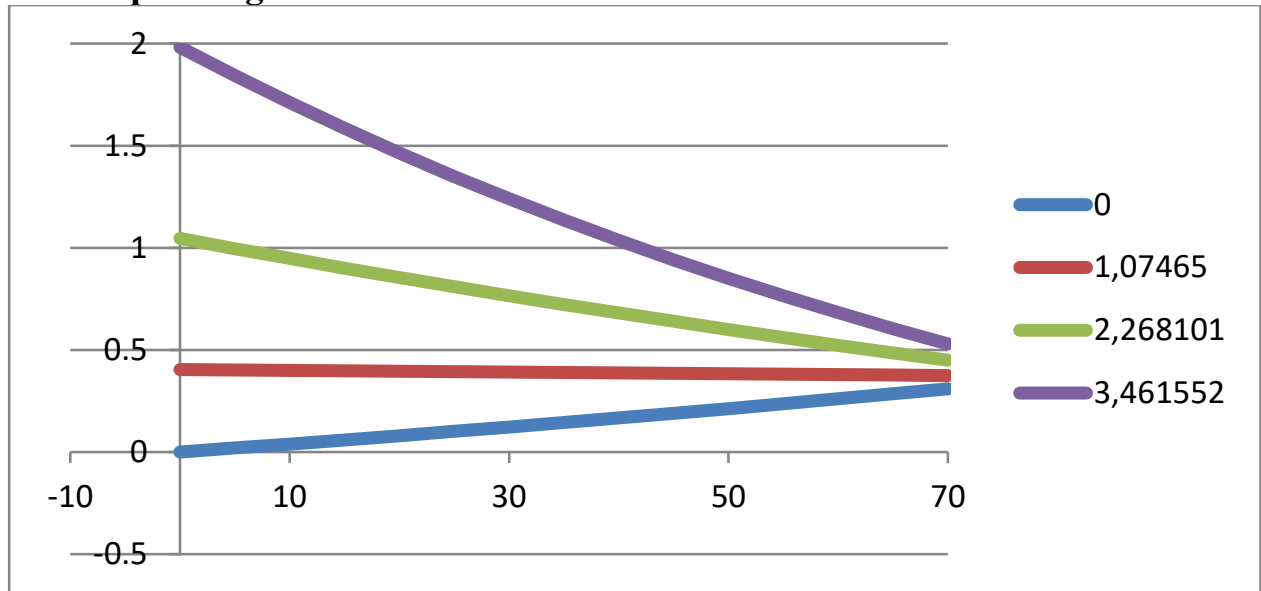

\section{Outside ties}

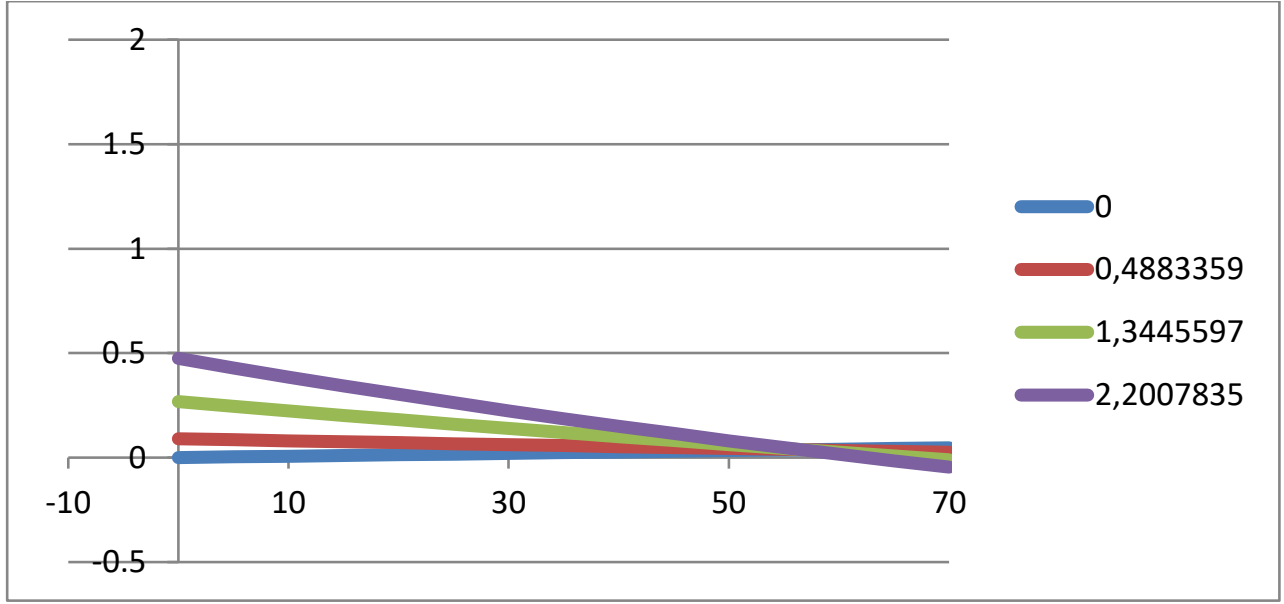

\section{Inside ties}

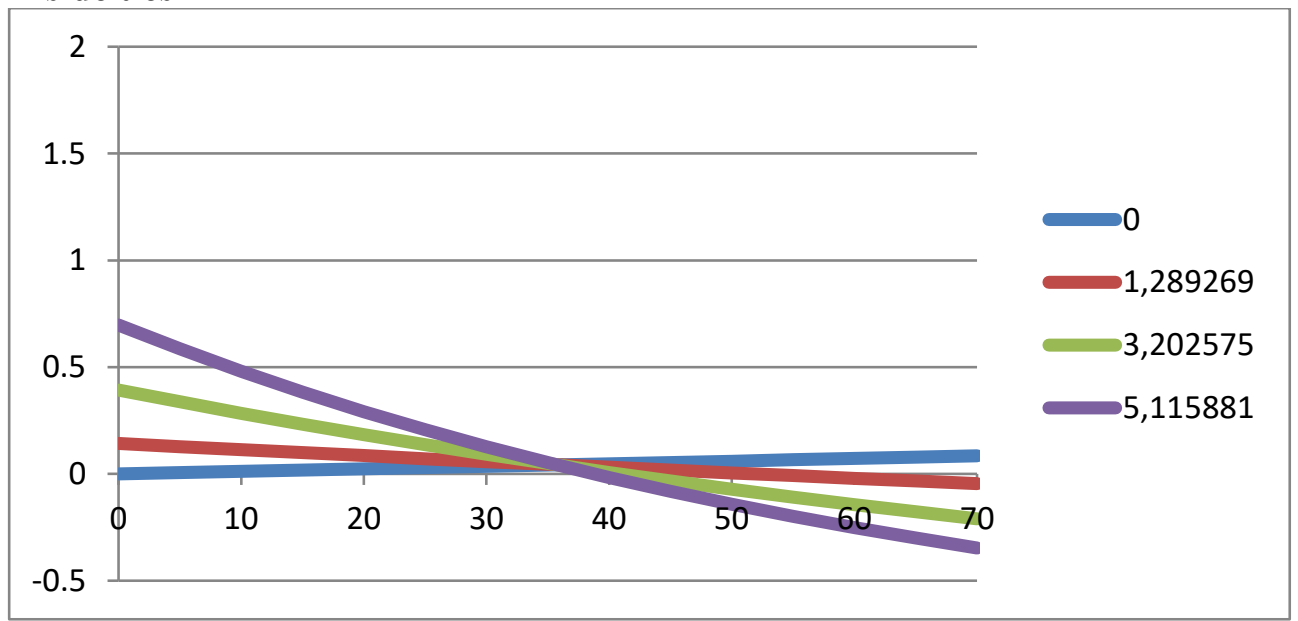

Notes: - Horizontal axis represents technological capital

- The for lines represent respectively the number of ties $(0$, mean, mean +1 std dev; mean +2 std dev $)$ 
